NOTES

\title{
EXECUTIVE ORDER 12,333: AN ASSESSMENT OF THE VALIDITY OF WARRANTLESS NATIONAL SECURITY SEARCHES
}

On December 4, 1981, President Reagan signed Executive Order 12,333.1 Asserting that "[t]imely and accurate information about . . . foreign powers, organizations, and persons and their agents, is essential to the national security," 2 the Order sets forth guidelines to coordinate the agencies that form the national intelligence network ${ }^{3}$ in the conduct of intelligence activities. Despite purported consistency, with the Constitution and laws of the United States, ${ }^{4}$ these guidelines raise substantial and unresolved questions of constitutional law.

Section 2.5 of the Order empowers the Attorney General to authorize United States intelligence agencies to conduct intrusive surveillance without first obtaining a warrant, provided the Attorney General finds probable cause to believe that the subjects of the surveillance are foreign powers or their agents. ${ }^{5}$ Yet the Order also

1. Exec. Order No. 12,333, 3 C.F.R. 200 (1981 Comp.), reprinted in 50 U.S.C. $\$ 401$ (Supp. V 1981).

2. Exec. Order No. 12,333, 3 C.F.R. 200, 200.

3. The Intelligence Community consists of the Central Intelligence Agency (CIA), National Security Agency (NSA), Defense Intelligence Agency (DIA), offices within the Defense Department for the collection of specialized foreign intelligence through reconnaissance programs, and the Bureau of Intelligence and Research of the Department of State, as well as the imtelligence elements of the Army, Navy, Air Force, Marine Corps, Federal Bureau of Investigation (FBI), and the Departments of Energy and the Treasury. Id. \& 3.4(f).

4. See, eg., id $\$ 1.1$ (b) ("consistent with applicable Umited States law . . . and with full consideration of the rights of Umited States persons"); id $\$ 2.1$ ("collection of . . . information ... pursued in a vigorous, innovative and responsible manner that is consistent with the Constitution and applicable law and respectful of the principles upon which the United States was founded"); id. $\$ 2.8$ ("Nothing in this order shall be construed to authorize any activity in violation of the Constitution or statutes of the United States.")

5. Id. § 2.5. Section 2.5 provides:

The Attomey General hereby is delegated the power to approve the use for imtelligence purposes within the United States or against a United States person abroad, of any technique for which a warrant would be required if undertaken for law enforcement purposes, provided that such techniques shall not be undertaken unless the Attorney General has determined in each case that there is probable cause to believe that the technique is directed against a foreign power or an agent of a foreign power. Electronic 
provides $^{6}$ that the Attorney General and the agencies must abide by the specific requirements of the Foreign Intelligence Surveillance Act of 1978 (FISA), ${ }^{7}$ which exphicitly forbids the use of warrantless electromic surveillance within the United States to obtain intelligence concerning foreign countries. ${ }^{8}$ Consequently, although the agencies must currently secure a warrant before conducting foreign securityrelated electronic surveillance within the United States, they need not do so when conducting surveillance outside the borders of the country. In addition, the Order authorizes warrantless non-electronic surveillance $i m$ both the Umited States and foreign countries.

This note questions the validity of section 2.5.9 The note first examines the sources of executive power to conduct foreign intelligence surveillance and concludes that the fourth amendment limits that power, regardless of its source.10 After introducing the fourth amendment, ${ }^{11}$ the note traces the history of warrantless surveillance for national security purposes and its interrelationship with judicial treatinent of electronic surveillance. ${ }^{12}$ After examining several

surveillance, as defined in the Foreign Intelligence Surveillance Act of 1978 , shall be conducted in accordance with that Act, as well as this Order.

Section 2-201 of Exec. Order No. 12,036, 3 C.F.R. 113 (1979), impleinented by the Carter Administration, similarly authorized the Attorney General to conduct warrantless searches.

6. Foreign Intelligence Surveillance Act of 1978, 50 U.S.C. $\$ \$ 1801-1811$ (Supp. V 1981).

7. For a more detailed analysis of the FISA see infra notes 95-104 and accompanying text.

8. See Exec. Order No. 12,333, $\$$ 2.5, 2.8, 3 C.F.R. 200, 212-13 (1982).

9. The extent to which section 2.5 of the Order has been used is not a matter of public record. However, in United Presbyterian Clurch in the U.S.A. v. Reagan, 557 F. Supp. 61 (D.D.C. 1982), thirty-six plaintiffs brought a consolidated action challenging the constitutionality of the Order. The plaintiffs, imcluding a number of left-wing political organizations and individuals, as well as religious organizations, journalists, and academics, asserted that they were in imminent apprehension of being considered "agents of a foreign power" because of their contact with foreign nations. They sought declaratory relief, stating that the Order violates: (1) article 1, section 1 of the Constitution, designating Congress as the lawmaker of the national government; (2) the first amendenent, by allowing thein to be considered "agents of a foreign power" through an "unprincipled discretionary decision based solely on ... political behiefs, statements and associates", by chilling free speech and free exercise of religion, and by violating the establishment clause; (3) the fourth amendunent, by permitting certain intelligence-gathering activities otherwise prohibited absent a warrant procured froun a neutral magistrate; (4) the fifth amendinent, by infringing the right to travel, by depriving plaintiffs of funds invested for the purpose of obtaining privacy of lome and office, and by unconstitutional vagueness and overbreadth. The plaintiffs also sought to enjoin enforcement of the Order. On October 20, 1981, Judge Gesell granted defendants' motion to dismiss for lack of subject natter jurisdiction. concluding that plaintiffs' mere " 'fear' and 'concern' that they 'may be targeted' for mtelligencegathering activities" failed to allege a redressable concrete injury as required by the case and controversy standard of Article III. Id at 63; see also Halkin v. Helms, 690 F.2d 997, 1001-03 (D.C. Cir. 1982) (denying standing to protest constitutionality of executive order on national security because plaintiff asserted inere generalized grievance).

10. See infra notes $15-34$ and accompanying text.

11. See infra notes $35-49$ and accompanying text.

12. See infra notes 50-115 and accompanying text. 
arguments that favor a general national security exception to the warrant requirement of the fourth amendment, the note concludes that such an exception cannot be constitutionally justified. ${ }^{13}$ Alternatively, the note concludes that the legislative history of the Foreign Intelligence Surveillance Act and other congressional proceedings reveal that Congress has preempted any claimed presidential prerogative to conduct warrantless foreign intelligence surveillance. ${ }^{14}$ Under either analysis, section 2.5 is an unauthorized exercise of presidential power.

\section{Sources of Executive Power to Conduct National SECURITY SEARCHES}

Presidential power to collect information relating to national security stems from one or more of three theoretical bases: (1) inherent extra-constitutional executive power, ${ }^{15}$ (2) power inextricably linked to and necessitated by powers expressly granted in the Constitution; and (3) power legislatively granted to the executive. Whatever its source, however, presidential power must be exercised consistently with certain constitutional constraints.

In his celebrated opinion in United States v. Curtiss-Wright Export Corp. ${ }^{16}$ Justice Sutherland extolled the "plenary and exclusive power of the President as the sole organ of the Federal government in the field of international relations." 17 Sutherland concluded in dicta ${ }^{18}$ that the federal government derives its power in foreign affairs from an extraconstitutional source. ${ }^{19}$ Without clearly articulatimg the scope of his

\section{See infra notes $116-41$ and accompanying text.}

14. See infra notes $142-80$ and accompanying text.

15. Throughout this note, "inherent powers" refers to those powers so inextricably linked to the executive office that the President need not look to the Constitution for their source.

16. 299 U.S. 304 (1936).

17. Id. at 320.

18. See Youngstown Sheet \& Tube Co. v. Sawyer, 343 U.S. 579, 635-36 n.2 (1951) (Jackson, J., concurring) (Curtiss-Wright "involved, not the question of the President's power to act without congressional authority, but the question of his right to act under and in accord with an Act of Congress. . . . Much of the Court's opinion is dictum . . . ."). Curtiss-Wright actually concerned the constitutionality of a statute. In the presidential proclamation at issue, President Roosevelt claimed to be "acting under and by virtue of the authority conferred . . . by the . . . joint resolution of Congress." Curtiss-Wright, 299 U.S. at 313.

19. Curtiss-Wright, 299 U.S. at 315-16. Justice Sutherland reasoned that, in drafting the Constitution, the several states intended to delegate certain powers they previously possessed to the federal government. Asserting that the individual states had never possessed intemational powers, Sutherland concluded that the federal government derived such powers from another source. Relying on an unbroken-chain-of-sovereignty theory, he declared that power over international affairs had passed, like a royal sceptre, from the British crown to the fledgling American government. Id. at 316-17. 
analysis, he identified the President as the primary representative of the United States in the international field. ${ }^{20}$ On its face, Sutherland's theory conflicts with a basic premise of American constitutional law: that the federal government, unlike the governments of the several states, is one of limited powers - those explicitly granted in the Constitution and those fairly deeined "necessary and proper" to the effective exercise of the express powers. ${ }^{21}$ Sutherland's dictuin has been subject to scholarly attack, ${ }^{22}$ and the Court seenis to have rejected it. ${ }^{23}$

In any event, Sutherland recognized that the President's supposed "inherent" powers, like all powers of the federal government, are subject to the fundaniental restrictions enumerated in the Bill of Rights. ${ }^{24}$

\footnotetext{
20. Not only . . . is the Federal power over external affairs in origin and essential character different from that over internal affairs, but participation in the exercise of the power is significantly limited. In this vàst external realm, with its important, coinphicated, delicate and inanifold problems, the President alone has the power to speak or listen as a representative of the nation.
}

Id. at 319. Sutherland did not explain the degree to which the foreign affairs power is allocated by the Constitution between the Congress and the President. For an illuminating depiction of this allocation, see United States v. Butenko, 494 F.2d 593, 632-33 (3d Cir. 1974) (Gibbons, J., dissenting). Judge Gibbons, accepting argnendo the first part of Sutherland's argnement, nnaintained that "it is one thing to say that the federal government succeeded to the foreign affairs prerogatives of George III. It is quite another to say that those prerogatives have passed fron George III to George Washington and in unbroken succession to Richard Nixon." Id. at 630-31.

Sutherland was under no pressure to clearly distinguish the presogatives of the several branches in foreign affairs since Roosevelt acted pursuant to a congressional act. See supra note 18.

21. See, eg., Marbury v. Madison, 5 U.S. (1 Cranch) 137, 177 (1803); McCulloch v. Muryland, 17 U.S. (4 Wheat) 316, 405 (1819) ("This government is acknowledged by all to be one of enumerated powers. The principle, that it can exercise only the powers granted to it . . . is now universally admitted.")

22. See, eg., Berger, The Presidential Monopoly of Foreign Relations, 71 Mich. L. Rev. 1 (1972); Borchard, Treaties and Executive Agreements - A Reply, 54 YALE L.J. 616, 648 (1945); Fulbright, American Foreign Policy in the 20th Century Under an 18th Century Constitution, 47 CORNeLl L.Q. I (1961); Levitan, The Foreign Relations Power: An Analysis of Mr. Justice Sutherland's Theory, 55 YALE L.J. 467, 497 (1946) ("as long as we live under . . . [a written constitution] there appears little roon for a theory of 'inherent' powers. . . The Sutherland doctrine, however, makes shambles out of the very idea of a constitutionally limited government."); Lofgren, United States v. Curtiss-Wright Export Corporation: An Historical Reassessment, 83 YALE L.J. 1 (1973); Schlesinger, Congress and the Making of American Foreign Policy, 51 Foreion AFF. 78 (1972).

23. "[T] $]$ he President's power, if any, . . . must stein either from an act of Congress or from the Constitution itself" Dames \& Moore v. Regan, 453 U.S. 654, 668 (1981) (quoting Youngstown Sheet \& Tube Co. v. Sawyer, 343 U.S. 579,585 (1952)).

24. The "inherent" power in international affairs nust "like every other governmental power ... be exercised in subordination to the applicable provisions of the Constitution." CurtissWright, 299 U.S. at 320, see also Zweibon v. Mitchell, 516 F.2d 594, 621 (D.C. Cir. 1975) (en banc), cert. denied, 425 U.S. 944 (1976); Note, Foreign Security Surveillance and the Fourth Amendment, 87 HARv. L. Rev. 976, 978-79 (1974).

In this respect, any inherent power that exists in foreign affairs is similar to the treaty power described in Missouri v. Holland, 252 U.S. 416 (1920): 
Subordinating the Bill of Rights to vague and amorphous "inherent" powers ${ }^{25}$ would substantially undermine its purposes. ${ }^{26}$ Instead, these constitutional restrictions offer hope of delimiting those ill-defined powers in a coinprehensible and inanageable way. Any "inherent" power that might rest in the executive inust be exercised in accordance with the fourth amendment.

Presidential power to conduct foreign intelligence surveillance can be premised also on express constitutional grants. ${ }^{27}$ In McCulloch $v$.

Acts of Congress are the supreme law of the land only when made in pursuance of the Constitution, while treaties are declared to be so when inade under the authority of the United States. [U.S. CoNST. art. VI] . . . It is obvious that there may be matters of the sharpest exigency for the national well being that an act of Congress could not deal with but that a treaty followed by such an act could. . . . The Treaty in question does not contravene any prohibitory words to be found in the Constitution.

Id at 433 (emphasis added).

In Reid v. Covert, 354 U.S. 1 (1957), Justice Black wrote in the plurality opinion:

It would be manifestly contrary to the objectives of [the Founding Fathers] . . - let alone alien to our entire coustitutional history and tradition - to construe Article VI as permitting the United States to exercise power under an international agreement without observing constitutional prohibitions.

Id. at 17. The Reid Court held that the President cannot, pursuant to an executive agreement, deprive the spouses of United States soldiers, although stationed overseas, of their constitutional right to a jury trial.

25. "Loose and irresponsible use of adjectives colors all non-legal and much legal discussion of presidential powers. 'Inherent' powers, 'implied' powers, 'incidental' powers, 'plenary' powers, 'war' powers and 'emergency' powers are used, often interchangeably and without fixed or ascertainable meanings." Youngstown, 343 U.S. at 646-47 (Jackson, J., concurring).

26. Cf. New York Times Co. v. United States, 403 U.S. 713, 719 (1971) (Black, J., concurring) ("To find that the President has 'inherent power' to halt the publication of news by resort to the courts would wipe out the First Amendment and destroy the fundamental liberty and security of the very people the government hopes to make 'secure.' . . . The word 'security' is a broad, vague generality whose contours should not be invoked to abrogate the fundamental law embodied in the First Amendinent.").

27. No provision in the Constitution deals specifically with the collection of foreign intelligence. Some of the explicit powers of the President that relate to foreign affairs are: (1) Commander-in-Chief, U.S. CoNST. art. II, § 2, cl. 1; (2) Power to make treaties, U.S. CoNST. art. II, $\S 2$, cl. 2; (3) The "executive Power," U.S. CoNST. art. II, \& 1, cl. 1. Sonie have tried to interpret the executive power broadly, matching the language of article II, section 1, clause 1 ("The executive Power shall be vested in a President") against that of article I, section 1 , clause 1 ("All legislative powers herein granted shall be vested in a Congress") (enuphasis added). They assert that the language indicates that the President possesses certain powers not enumerated in the Constitution. The first recorded use of this argument was by Alexander Hamilton, publishing under the pseudonym of Publius, when he battled with James Madison (Helvetius) over the extent of presidential pewer after President Washington issued the neutrality proclamation in 1793, following the eruption of war between France and Great Britain. See generally E. CoRwin, The PresidenT: OFFICE AND POWERs, 1787-1957: History \& ANALysis of Practice \& OpINION (1974). In effect, this reading would impert Justice Sutherland's concept of extra-constitutional powers into the language of the Constitution itself. The Court has not looked favorably on this expansive reading of executive power. See, eg., Youngstown Sheet \& Tube Co. v. Sawyer, 343 U.S. 579, 641 (1951) (Jackson, J., concurring) ("The example of such unlimited executive power that must have most impressed the forefathers was the prerogative exercised by George III, and the description of its evils in the Declaration of Independence leads me to doubt that they were creating their new 
Maryland, ${ }^{28}$ Chief Justice Marshall, in determining that Congress unay charter a national bank despite the absence of express authorization in the Constitution, found that a "government which has a right to do an act . . . inust, according to the dictates of reason, be allowed to select the ineans." 29 However, only those means appropriate and plainly adapted to legitimate ends "which are not prohibited, but consist[ent] with the letter and spirit of the Constitution, are constitutional." 30 Thus, any powers that the President may possess ancillary to those expressly granted in the Constitution nust be exercised subject to its restraints. ${ }^{31}$ Limitations on ancillary and "inherent" powers do not differ in this respect.

executive in his image. ... I cannot accept the view that this clause is a grant in bulk of all conceivable executive power but regard it as an allocation to the presidential office of the generic powers thereafter stated.")

28. 17 U.S. (4 Wheat.) 316 (1819).

29. Id at 409-10. For an application of this theory to the executive branch, see United States v. Nixoin, 418 U.S. 683 (1974), in which the Court stated that

. . the silence of the Constitution ... [concerning executive privilege] is not dispositive. "The rule of constitutional interpretation announced in McCulloch v. Maryland, 4 - Wheat. 316, that that which was reasonably appropriate and relevant to the exercise of a

"granted power was to be considered as accompanying the grant, has been so universally applied that it suffices merely to state it."

Id. at 705 n.16 (quoting Marshall v. Gordon, 243 U.S. 521, 537 (1917)).

It is unclear, however, precisely to what extent the President needs congressional approval before he may exercise ancillary powers. The preeminence of Congress in determining what powers are "necessary and proper" to the exercise of those expressly granted is dictated by the language of article I, section 8, clause 18 (The Congress shall have power to "make all Laws which shall be necessary and proper for carrying into execution the foregoing Powers, and all other Powers vested by this Constitution in the Government of the United States, or in any Department or Officer thereof."). Although in the first instance Marshall's analysis in McCulloch relied on common sense, he bolstered his argument by relying on the "necessary and proper" clause. Marshall's opinion addressed whether the governunent as a whole possessed the requisite power to charter a national bank. It did not deal with how such power should be allocated between the several branches. For a thoughtful analysis of the preemptive nature of congressional power under the necessary and proper clause, see Van Alstyne, The Role of Congress in Determining Incidental Powers of the President and of the Federal Cours: A Comment on the Horizontal Effect of the Sweeping Clouse, LAW \& CONTEMP. ProBs., Spring 1976, at 102. The article proposes that the necessary and proper clause assigns to Congress alone the responsibility to establish by law what additional authority, if any, the executive and the courts are to have beyond the core of powers that are indispensable, rather than inerely appropriate or helpful, to the performance of their express duties under articies II and III of the Constitution. Id at 107. Accord Youngstown, 343 U.S. at 588-89 (Congress has "exclusive constitutional authority to make laws necessary and proper to carry out the powers vested by the Constitution."). But see id at 640 (Jackson, J., concurring) (enumerated powers should be given "the scope and elasticity afforded by what seem to be reasonable, practical implications instead of the rigidity dictated by doctrinaire textualism."). See generally Myers v. United States, 272 U.S. 52 (1926) (upholding President's power to unilaterally terminate postal employee appointed with consent of the Senate); infra notes 142-54 and accompanying text.

30. McCulloch, 17 U.S. (4 Wheat) at 421.

31. Cf. United States v. United States District Court, 407 U.S. 297, 320 (1972) ("We recognize . . the constitutional basis of the President's domestic security role, but we think it must be exercised in a manner compatible with the Fourth Amendinent."). 
Finally, although the President may receive power under a congressional grant, ${ }^{32}$ Congress has never enacted legislation explicitly authorizing the President to engage generally in warrantless national security surveillance. Indeed, the FISA imposes an obligation on the executive to obtain a warrant before conducting electronic surveillance to acquire foreign intelligence. ${ }^{33}$ Even liad Congress purported to grant the executive this power, it could not have done so in disregard of the fourth amendment. Congress and the President, each individually bound to observe constitutional restrictions, also must do so when acting in concert. The executive, unable to hurdle the restrictions of the Constitution alone, cannot leapfrog thcm in tandem with Congess. ${ }^{34}$

32. The power of Congress under the "necessary and proper" clause has been discussed. See supra note 29. Recall, however, that Curriss-Wright actually involved a legislative delegation of power to the President. See supra note 18.

33. See infra notes 95-104 and accompanying text.

34. But see New York Times Co. v. United States, 403 U.S. 713 (1971) (the Pentagon Papers case). Three justices - Black, Douglas, and White - explicitly noted that Congress had passed no statute authorizing the executive to impose prior restraints on the publication of material sensitive to national security. Id. at 718 (opinion of Black, J.), 720-22 (opirion of Douglas, J.), 732 (opinion of White, J.). In United States v. Progressive, 467 F. Supp. 990 (E.D. Wis. 1979), dismissed, 610 F.2d 819 (7th Cir. 1979), the district judge supported his imposition of prior restraint with the implication of these three justices that an authorizing act by Congress inight be constitutionally relevant. Id. at 995 . He granted the government's request for a preliminary injunction against publication of an article relating to the design of atomic weaponry, relying on section 2274 of the Atomic Energy Act, which prohibits communication of restricted data to any person if there is reason to believe that the data will be used to injure the United States. The implication that an infringement on speech, unconstitutional when imposed unilaterally by a public officer, can be legitimized by the imprimatur of the legislature seems incompatible with the language of the aunendment: "Congress shall make no law . . . abridging the freedom of speech." U.S. Const. ainend. 1 .

Perhaps the dicta in New York Times, which was decided hastily on expedited review, should be accorded limited weight. Certainly it is unlikely that Justice Black, the first amendinent absolutist, would have decided the case differently had congressional action been involved.

Possibly the emphasis on the absence of statutory authorization represented only an attempt to provide an alternative basis for the New York Times decision. Not only did the prior restraint violate the first anendment, but the President and the federal courts, by cooperating to restrain free speech without congressional authorization, exceeded the legitimate scope of their authority. Viewed in this fashion, New York Times raises issues identical to those discussed regarding the preemptive nature of congressional power under the necessary and proper clause.

Alternatively, the dicta might apply only to first amendment adjudications. That amendment differs from other guarantees contained in the Bill of Rights by its all-embracing sweep: Congress shall make no law. Qualifying language appends most other guarantees. For example, the fourth aunendment provides protection from "unreasonable" searches and seizures. The fifth amendment proscribes any deprivation of life, liberty, or property "without due process of law." Similarly, the sixth aunendment prohibits "cruel and unusual" punishments. The Court, lowever, has not seen fit to protect all speech and has, of necessity, utilized referents external to the Constitution to determine whether the anendment is applicable. The Court has considered whether given speecl is semantically included in "the freedom of speech" protected by the ainendment. See Van Alstyne, A Graphic Review of the Free Speech Clause, 70 CAL. L. REv. 107, 11416 (1982). Thus, congres- 
Whatever the source of executive power, it remams subject to the constraints of the Constitution.

\section{The Fourth Amendment and National Security SURVEILLANCE}

\section{A. Background of the Fourth Amendment.}

The fourth ainendment to the Umited States Constitution provides that "[t]he right of the people to be secure in their persons, houses, papers, and effects, against unreasonable searches and seizures, shall not be violated, and no Warrants shall issue, but upon probable cause, supported by oath or affirmation, and particularly describing the persons or things to be seized."3s The Supreme Court interprets this somewhat ambiguous language to preclude warrantless searches even when such searches are otherwise reasonable.

The Fourth Amendment contemplates a prior judicial judgment, not the risk that executive discretion may be reasonably exercised. This judicial role accords with our basic constitutional doctrine that individual freedoms will best be preserved through a separation of powers and division of functions among the different branches and levels of government. ${ }^{36}$

In other words, searches undertaken without a judicial warrant, absent exigent circumstances, ${ }^{37}$ are unreasonable per se.

The rationale for a strong warrant clause is compelling. The authors of the fourth amendment intended to remove unfettered discretion from the hands of the executive, placing their faith in a neutral and

sional acquiescence in an executive judgment that given speech so threatens the national security as to be outside the first amendment's protection might indeed be relevant to the amendment's applicability. The fourth amendment, on the other hand, indisputably protects the "right of the people to be secure" from all unreasonable searches and seizures. It is for the Court to determine what searches are reasonable, and thus far the Court has never intimated that congressional acquiescence in a search is related to its reasonableness. In effect, this would delegate to Congress the power to determine the substantive scope of the amendment, thus usurping the judicial function. See Marbury v. Madison, 5 U.S. (1 Cranch) 137, 177 (1803) ("It is emphatically the province and duty of the judicial department to say what the law is."); cf. Oregon v. Mitchell, 400 U.S. 112, 249 n.31 (1970) (Brennan, J., concurring) (section 5 of the fourteenth amendment does not grant Congress the power to enact statutes that would limit or dilute the Court's interpretation of constitutional provisions); Katzenbach v. Morgan, 384 U.S. 641,651 n. 10 (1966).

35. U.S. CoNST. amend. IV.

36. United States v. United States District Court, 407 U.S. 297,317 (1972); see also Robbins v. California, 453 U.S. 420, 423 (1981); Michigan v. Summers, 452 U.S. 692, 703-04 (1981); Steagald v. Uuited States, 45I U.S. 204, 212-15 (1981); Almeida-Sanchez v. United States, 413 U.S. 266, 280-82 (1973) (Powell, J., concurring); Coclidge v. New Hampshire, 403 U.S. 443, 454-55 (1971); Chimel v. California, 395 U.S. 752, 762 (1969); Terry v. Ohio, 392 U.S. I, 20 (1968); Katz v. United States, 389 U.S. 347, 357 (1967); Camara v. Municipal Court, 387 U.S. 523, 528-29 (1967).

37. See cases cited infra note 46. 
detached magistrate. ${ }^{38}$ Furthermore, pre-screening prospective searches is the only practical way to enforce the amendment. The Biv$e n s^{39}$ action for money damages for fourth amendment violations is an imperfect remedy because national security surveillance is, by its very nature, shrouded in secrecy. A victim, oblivious to violations of his rights, will have no occasion to vindicate them in court. Another enforcement mechanism, the exclusionary rule, ${ }^{40}$ deters violations of fourth amendment rights, if at all, only when the government would otherwise use illegally seized evidence in a criminal prosecution.

Moreover, the efficacy of both the Bivens action and the exclusionary rule to deter fourth amendment violations is widely disputed. ${ }^{41}$ In contrast, the warrant requirement, explicitly supported by the language of the amendment, ${ }^{42}$ attempts to prevent incipient violations rather than impose after-the-fact sanctions. ${ }^{43}$ Finally, even if judges virtually

38. See supra text accompanying note 36 .

39. Bivens v. Six Unknown Named Agents of the Federal Bureau of Narcotics, 403 U.S. 388 (1971).

40. The exclusionary rule prohibits introduction in criminal cases of evidence acquired in violation of the fourth amendment. See, e.g., Mapp v. Ohio, 367 U.S. 643 (1961); Elkins v. United States, 364 U.S. 206 (1960); Weeks v. United States, 232 U.S. 383 (1914).

41. See, e.g., Stone v. Powell, 428 U.S. 465, 496.502 (1976) (Burger, C.J., concurring); Goodpaster, An Essay on Ending the Exclusionary Rule, 33 Hastings L.J. 1065 (1982); Comment, Contempt of Court as an Alternative to the Exclusionary Rule, 72 J. CRM. L. \& CRIMINologY 993 (1981); Note, The Limits of Implied Constitutional Damages Actions: New Boundaries for Bivens, 55 N.Y.U. L. REv. 1238 (1980); Comment, Is It Time for a Change in the Exclusionary Rule? Umited States v. Williams and the Good Faith Exception, 60 WASH. U.L.Q. 161 (1982); N.Y. Times, Feb. 9, 1981, at Al, col. 4 (Chief Justice Burger argued that "[o]ur search for justice must not be twisted into an endless quest for technical errors, unrelated to guilt or innocence."). Certainly, the admissibility of illegally seized evidence in grand jury proceedings, see United States $v$. Calandra, 414 U.S. 338 (1974), and for impeachment purposes, see Walder v. United States, 347 U.S. 62 (1954); Note, Criminal Law-Evidence-Impeachment by Illegally Seized Extrinsic Evidence, 24 WAYNE L. REv. 1753 (1978), dilutes any deterrent force that the exclusionary rule might possess. The Bivens action, by allowing a good faith defense, denies compensation in many cases in which constitutional violations have occurred.

42. The text of the fourth amendment does not refer to a civil action for monetary damages or explicitly require that illegally seized evidence be deemed inadmissible in criminal cases. It does, on the other hand, specifically mention warrants: "[N]o Warrants shall issue, but upon probable cause, supported by oath or affirmation, and particularly describing . . . the persons or things to be seized." The protections of this clause would indeed be illusory had its authors intended that searches generally be undertaken without a warrant when the prerequisite conditions for a warrant do not exist.

43. In another respect, lowever, an across-the-board warrant requirement bears some similarity to the exclusionary rule. The deterrent rationale of the exclusionary rule looks beyond the guilt or innocence of the particular defendant against whoun the challenged evidence is presented to a goal of general compliance with the fourth amendment. Similarly, when a warrant has not been obtained, courts iguore the actual reasonableness of the particular search in the belief that the amendment will better protect individual rights if the executive must secure judicial approval before conducting searches. See cases cited supra note 36. 
rubber-stamp warrant requests, ${ }^{44}$ the procedure forces the executive to articulate the reasons for a search in language that will be convincing beyond the immediate circle of those proposing to conduct the search. This discipline inay well "serve to screen out requests that should not in good conscience be made." 45

Nevertheless, courts have created certain limited exceptions to the general warrant requirement ${ }^{46}$ where the warrant process would unduly frustrate the purposes of the proposed search. ${ }^{47}$ The constitutionality of section 2.5 depends on the existence of a foreign security exception. The Supreme Court has not ruled on the issue, ${ }^{48}$ however, and the lower courts are divided. ${ }^{49}$

\section{B. The National Security Exception.}

1. The history of the exception. As historically developed, the national security "exception" to the warrant requirement has been entwined with electronic surveillance, a relatively recent technological innovation. In 1928, in Olmstead $v$. United States, ${ }^{50}$ the Supreme Court placed electronic surveillance outside the ambit of the fourth amendnuent, holding that the fourth amendinent protects only against trespassory searches and seizures.51 Justice Brandeis entered an eloquent dissent, urging that the amcndinent protected personal rights of security and privacy. ${ }^{52}$ During the late 1930 's, in the Nardone ${ }^{53}$ decisions, the Court construed section 605 of the Federal Communications Act of

44. For instance, the special panel of judges established by the FISA to screen executive applications to conduct foreign intelligence electronic surveillance, see infra note 99 , has never refused to grant an application for electronic surveillance. See J. BAMFord, The PUzzLe PaLACE: A REPORT ON AMERICA's MOST SECRET AGENCY 370 (1982).

45. Lacovara, Presidential Power 10 Gather Intelligence: The Tension Between Article II and Amendment IV, LAw \& Conteap. ProBs., Summer 1976, at 106, 128.

46. Almeida-Sanchez v. United States, 413 U.S. 266, 272 (1973) (border searclr); Chimel v. California, 395 U.S. 752, 763-65 (1969) (search incident to arrest); Terry v. Ohio, 392 U.S. 1, 19-20 (1967) (stop and frisk); Camara v. Municipal Court, 387 U.S. 523, $539-40$ (1967) (einergency administrative search) (dictum); Schmerber v. California, 384 U.S. 757, 770-71 (1966) (exigent circumstances); Carroll v. United States, 267 U.S. 132, 15456 (1925) (search of a vehicle).

47. See infra notes $116-24$ and acconpanying text.

48. See infra note 74 and acconpanying text.

49. See infra notes $75-94$ and acconipanying text.

50. 277 U.S. 438 (1928).

51. Id. at $464-66$.

52. Id at 474-75 (Brandeis, J., dissenting).

The makers of our Constitution undertook to secure conditions favorable to the pursuit of happiness. They recognized the significance of man's spiritual nature, of his feelings and of his intellect. Thcy knew that only a part of the pain, pleasure and satisfactions of life are to be found in material things. They sought to protect Americans in their beliefs, their thoughts, their emotions and their sensations. They conferred, as against the government, the right to be let alone - the most counprehensive of rights and the right most valued by civilized nen. To protect that right, every unjustifiable intrusion by the gov- 
$1935,^{54}$ which banned wiretaps, to apply to law enforcement officers, but held only that wiretaps and the fruits of wiretaps were inadmissible as evidence in criminal prosecutions. ${ }^{55}$ The Justice Department, drawing some support from the language of section 605 , which arguably prohibited only divulging information, ${ }^{56}$ continued to conduct wiretaps for purely investigative purposes. ${ }^{57}$ In the 1940 's, two presidential directives explicitly advocated the use of electronic surveillance in cases involving the national security, 58 and between 1940 and 1964 the Justice Department conducted 6769 telephone wiretaps and installed 1984 microphones. 59 In 1965, lowever, President Johnson mitiated a policy authorizing federal agencies to intercept telephone conversations only in investigations relating to national security and only with the approval of the Attorney General, ${ }^{60}$ reducing the level of government

ernment upon the privacy of the individual, whatever the means einployed, must be deemed a violation of the Fourth Amendment.

Id. at 478.

53. Nardone v. United States, 308 U.S. 338 (1939); Nardone v. Umited States, 302 U.S. 379 (1937)

54. Ch. 652, Title VI, \& 605, 48 Stat. 1103 (1934), as amended, 47 U.S.C. $\$ 605$ (1976) ("No person not being authorized by the sender shall intercept any radio communication and divulge or publish the existence, contents, substance, purport, effect, or meaning of such intercepted communication to any person").

55. Nardone, 302 U.S. at $380-81$.

56. The Department drew special encouragement from the conjunctive language of section 605: "intercept . . . and divulge." See supro note.54. The Justice Department contended that merely disseminating intelligence information acquired by an interception throughout the agencies of the executive branch did not amount to divulgence under the statute. See Electronic Surveillance Within the United States for Foreign Intelligence Purposes: Hearings Before the Subcomm. on Intelligence and the Rights of Americans of the Senate Select Comm. on Intelligence, 94th Cong., 2d Sess. 24 (1976) (prepared statement of Attorney General Levi) [hereinafter cited as Levi].

57. The interpretation of the Justice Department was never tested in the courts. Because illegally obtained information was not admissible in criminal prosecutions, victims, who typically would have no occasion to discover that clandestine activity had been directed against them, had no opportunity to bring complaints before the courts.

58. President Roosevelt issued a confidential memorandum to the Attorney General on May 21, 1940, directing him "to secure information by listening devices direct[ed] to . . . communications of persons suspected of subversive activities against the Government . . ., including suspected spies." Memoranduns froin President Roosevelt to Attorney General Jackson, reprinted in Zweibon v. Mitchell, 516.F.2d 594, 674 (D.C. Cir. 1975) (en banc), cert. denied, 425 U.S. 944 (1976) (appendix A); see also Levi, supro note 56, at 24.

Attorney General Tom Clark suggested in a letter to President Harry Truman on July 17, 1946, that it was "imperative to use [electronic surveillance] . . . in cases vitally affecting the domestic security, or where human life is in jeopardy." The President concurred in the letter. Letter from Attorney General Clark to President Truman, July 17, 1946, reprinted in Zweibon, 516 F.2d at 674 (appendix A).

59. Levi, supra note 56, at 25.

60. Memorandum for the Heads of Executive Departments and Agencies, President Lyndon Johnson, June 30, 1965, reprinted in Zweibon, 516 F.2d at 67475 (appendix A). 
surveillance. 61

In 1967, the Supreme Court overruled Olmstead in Katz v. United States ${ }^{62}$ holding that the protections of the fourth amendment extend to non-trespassory electronic surveillance. According to the Court, the amendinent protects people and their reasonable expectations of privacy, not places. $^{63}$ The Katz Court expressly reserved judgment, however, on whether a warrant should be required to conduct electronic surveillance for national security purposes. ${ }^{64}$ The following year, Congress enacted the Omnibus Crime Control and Safe Streets Act, ${ }^{65}$ which established wiretap procedures requiring a judicial warrant based on a finding of probable cause that a crime had been or was about to be committed.66 The Act, however, expressly denied any intent to restrict the constitutional powers of the President to act in the interest of national security. 67

In 1971, in United States v. United States District Court, 68 known generally as the Keith case, ${ }^{69}$ the Supreme Court resolved part of the

61. Between 1965 and 1975 , the government conducted 1470 wiretaps and installed 273 microphones. Levi, supra note 56, at 26-27.

62. 389 U.S. 347 (1967).

63. Id at 351 .

64. "Whether safeguards other than prior authorization by a magistrate would satisfy the Fourth Amendment in a situation involving the national security is a question not presented by this case." Id at $358 \mathrm{n} .23$. Justice White, concurring, felt that a warrant should not be required if the President and Attorney General considered the requirements of national security and authorized electronic surveillance as reasonable. Id at 364 (White, J., concurring). Justice Douglas, joined by Justice Brennan, concurring, viewed White's words to be "a wholly unwarranted green light for the Executive Branch," arguing that the amendment draws no lines between various substantive offenses and that only the judiciary is sufficiently detached, disinterested, and neutral to decide whether the requirements of the fourth amendment have been met. Id. at 359-60 (Douglas, J., concurring). For a comment on the peculiar presence of footnote 23 in the Katz opinion, see infra text accompanying note 113.

65. Omnibus Crime Control and Safe Streets Act of 1968, Pub. L. No. 90-351, 82 Stat. 197 (1968) (codified as amended at 18 U.S.C. $\$ \$ 2510-2520$ (1976 \& Supp. IV 1980)).

66. 18 U.S.C. $\& 2518(3)$ (1976). Prior to the Ommibus Act, evidence oblained from non-consensual wiretaps had been inadmissible in federal criminal prosecutions because section 605 , on which the Nardone decisions were based, was absolute in its prohibition: it did not provide for electronic surveillance based on probable cause.

67. Nothing contained in this chapter or in section 605 of the Communications Act of 1934, 47 U.S.C. $\& 605$ (1976), shall limit the constitutional power of the President to take such measures as he deems necessary to protect the Nation against actual or potential attack or other lrostile acts of a foreign power, to obtain foreign intelligence information deemed essential to the security of the United States, or to protect national security information against foreign intelligence activities. ...

18 U.S.C. $82511(3)$ (1976), repealed by Pub. L. No. 95-511, 92 Stat. 1797 (1978). See also infra notes $167-70$ and accompanying text.

68. 407 U.S. 297 (1971).

69. Judge Keith of the United States District Court for the Eastern District of Michigan had excluded certain evidence that the government sought to introduce in a criminal prosecution. See United States v. Lewis, 321 F. Supp. 1074 (E.D. Mich. 1971). 
issue reserved in Katz. Construing the Omnibus Act proviso ${ }^{70}$ as essentially neutral to any presidential power, ${ }^{71}$ the Keith Court held that surveillance "deemed necessary to protect the nation from attempts of domestic organizations to attack and subvert the existing structure of Government"72 requires a judicial warrant. Unfortunately, the Court did not define "domestic organizations" or furnish guidelines to differentiate them from international organizations. ${ }^{73}$ Indeed, such definitions, perhaps impossible to draw with clarity, may be constitutionally irrelevant. Subsequent Supreme Court decisions have not ruled on the constitutionality of warrantless security surveillance of non-domestic organizations or individuals. ${ }^{74}$

Four United States Courts of Appeals, though, have recognized a limited national security exception to the warrant requirement. In United States v. Brown, ${ }^{75}$ the Fifth Circuit denied Rap Brown, a civil rights activist charged with transporting firearms while under indictment, the right to examine ${ }^{76}$ the fruits of certain national security wiretaps on his telephone. Writing for the court, Judge Griffin Bell ${ }^{77}$ maintained that the president may authorize warrantless wiretaps to

70. See supra note 67.

71. 407 U.S. at 303.

72. Id at 309.

73. This definitional problem involves the same considerations surrounding the definition of "agent of a foreign power" in Executive Order 12,333. See supra note 9. Keith itself arose from a criminal prosecution alleging conspiracy to destroy a CIA office. No evidence, however, indicated either direct or indirect imvolvement by a foreign power. 407 U.S. at 309.

74. The Court has repeatedly rejected opportunities to rule on the constitutionality of warrantless security surveillance of non-domestic organization or individuals, denying certiorari in a nuniber of cases. See, e.g., Zweibon v. Mitchell, 516 F.2d 594 (D.C. Cir.) (en banc), cert. denied, 425 U.S. 944 (1976); United States v. Butenko, 494 F.2d 593 (3d Cir. 1973) (en banc), cert. denied, 419 U.S. 881 (1974); Umited States v. Brown, 484 F.2d 418 (5th Cir. 1973), cert. denied, 415 U.S. 960 (1974); Alderman v. United States, 394 U.S. 165 (1969) (granting certiorari but deciding the case on other grounds).

Perhaps the Court refrained from deciding the issue hoping that Congress would act to limit the exercise of executive power. Indeed, one court has indicated that in ultimately enacting the FISA Congress has

substantially reduced the importance of deciding in this case whether the Constitution independently requires the obtaining of a warrant for foreign intelligence electronic surveillance. ... [T] here is little if any need to apply the rule to a possible Fourth Amendment violation now that agents' conduct in the future will normally be guided and measured by statutory standards.

United States v. Aljouny, 629 F.2d 830, 842 (2d Cir.), cert denied, 449 U.S. 1111 (1980).

75. 484 F.2d 418 (5th Cir. 1973), cert. denied, 415 U.S. 960 (1974).

76. In Alderman v. United States, 394 U.S. 165 (1969), the Court held that a criminal defendant who has been victimized by illegal searches and seizures is entitled to disclosure of the searches and an adversary hearing on relevancy, ostensibly to determine if evidence used against him might be the fruit of an illegal search and thus excludable.

77. Griffin Bell was subsequently appointed Attorney General by President Carter and played a crucial role in steering the FISA through Congress. 
gather foreign intelligence:78 "Restrictions upon the President's power which are appropriate in cases of domestic security become artificial in the context of the international sphere."79

In United States v. Butenko, ${ }^{80}$ the Third Circuit undertook the unost thorough analysis of any federal appellate court recognizing a national security exception.81 Noting that "nothing in the language of the Constitution ... justif[ies] completely reunoving the Fourth Amendment's requirements in the foreign affairs field," 82 the court held the fourth amendment's reasonableness requirenent apphicable to all national security-related searches. The court did not require prior judicial approval, however, because the judiciary should not interfere with the continuous fiow of information on which efficient operation of the foreign pohcy-making apparatus depends. ${ }^{83}$ Judge Gibbons, discon-

78. Brown, 484 F.2d at 426; see also United States v. Clay, 430 F.2d 165 (5th Cir. 1970) (preKeith decision).

79. Brown, $484 \mathrm{~F} .2 \mathrm{~d}$ at 426.

80. 494 F.2d 593 (3d Cir. 1973) (en banc), cert. denied, 419 U.S. 881 (1974) (alien, allegedly involved in a plot to transmit the plan of a SAC command and control system to the U.S.S.R., sought disclosure and exclusion of certain wiretaps).

81. Indeed, the other circuits have not yet undertaken an involved analysis of the national security exception issue. In Brown, the Fifth Circuit simply reiterated its pre-Keith holding in United States v. Clay, 430 F.2d 165 (5th Cir. 1970), interpreting the Supreme Court's reference to the case in footnote 20 of Keith, 407 U.S. at 322 n.20, as a stamp of approval. Brown, 484 F.2d at 426.

Addressing the national security exception issue in United States v. Truong Dinh Hung, 629 F.2d 908 (4th Cir. 1980), the Fourth Circuit merely concluded that "because of the need of the executive branch for flexibility, its practical experience, and its constitutional competence, the courts should not require the executive to secure a warrant each time it conducts foreign surveillance." It at 914. According to the court, because privacy interests may be severely compromised, the warrant exception applies only when (1) the object of surveillance is a foreign power, its agents, or collaborators; and (2) the primary purpose of the search is to acquire foreign intelligence. Id at 915-16. The Fourth Circuit did not elaborate on the dynamics of its test. Presumably, the judiciary must determine whether the criteria are satisfied. If prior judicial determination is required, the Truong Dinh Hung court still requires the executive to submit to prior judicial scrutiny of the proposed search, whether or not one wishes to call it a warrant. On the issue of whetber judicial determination is necessary, however, the Butenko court found that "the better course is to rely, at least in the first instance, on the good faith of the Executive and the sanctions. for illegal surveillances incident to post-search criminal or civil litigation," 494 F.2d at 605, such as Bivens and the exclusionary rule.

In United States v. Buck, 548 F.2d 871, 875 (9th Cir. 1977), the Nintb Circuit stated simply that "[f]oreign security wiretaps are a recognized exception to the general warrant requirement."

82. Butenko, 494 F.2d at 603.

83. Id. at 605 . The court did not explain low imposition of a warrant requirement would impede the flow of foreign policy information. If the fourth amendinent applies, the government has no constitutionally recognized interest in conducting searches inconsistent with the reasonableness requirement. Therefore, nothing is lost by imposition of a warrant requirement on searches related to national security. See infra note 141 . It is possible that the court failed to distinguish the legitimate need of the Execulive to acquire foreign intelligence information, which is amenable to prior judicial scrutiny, from the executive's substantive power to collect foreign intelligence information without a warrent. 
certed by the potentially wide reach of the exception articulated by the majority, dissented. ${ }^{84} \mathrm{He}$ found implicit in the court's holding a recogmition of broad, inherent, extra-constitutional executive power ${ }^{85}$ nore attuned to contemporaneous events than the "clearly intended ineaning" of the Constitution. ${ }^{86}$ Judge Gibbons also did not understand how a warrant requirement would unduly limit executive power to conduct foreign affairs. ${ }^{87}$

A plurahty of the United States Court of Appeals for the District of Columbia Circuit, sitting en banc, echoed Judge Gibbons' views in Zweibon v. Mitchell. ${ }^{88}$ In Zweibon, the Jewish Defense League (JDL) sought monetary damages from John Mitchell and several FBI einployees for conducting warrantless electronic surveillance. The JDL had aroused Soviet antipathy by engaging in both peaceful and terrorist activities protesting the USSR's emigration policy. ${ }^{89}$ The Attorney General, fearing possible international embarrassnient or Soviet retaliation against American citizens, ${ }^{90}$ undertook the surveillance. Because foreign powers were indirectly involved, Keith did not apply. On the other hand, neither foreign powers nor their agents were the subjects of surveillance.91 The Zweibon plurality relied principally on the Supreme Court's reasoning in Keith and the standards laid out in Camara v. Municipal Court ${ }^{92}$ to require that a warrant be obtained "before a wiretap is installed on a domestic organization that is neither the agent of nor acting in collaboration with a foreign power, even if the surveillance is installed under presidential directive in the name of foreign intelligence gathering for the protection of the national secur-

84. The intimation of the majority that congressional action circumscribing the President's supposed authority to engage in warrantless searches might be unconstitutional, $494 \mathrm{~F} .2 \mathrm{~d}$ at 601 , particularly concerned Judge Gibbons. Id at 611,628 . Gibbons correctly contended that Congress may limit any power the president may possess in this area. Even the executive acknowledged this when Congress subsequently repealed the previous disclaimer provision, 18 U.S.C. \$ 2511(3) (1976), in enseting the FISA. See infro note 148 and accoinpanying text.

85. Gibbons referred to the majority's "gingerly ennbrace" of the Curtiss-Wright dictum. 494 F.2d at 628. For an analysis of United States v. Curtiss-Wright, 299 U.S. 304 (1936), see supra notes $16-25$ and accompanying text.

86. Butenko, 494 F.2d at 635 .

87. "In most instances . . . [the President's] agents could obtain a warrant. . . . The ouly instance where executive action could not be approved by the courts would be where there were no exigent circumstances or where no court could legally have issued a warrant." Id. at 637 .

88. 516 F.2d 594 (D.C. Cir. 1975) (en banc), cert. denied, 425 U.S. 944 (1976).

89. $516 \mathrm{~F} .2 \mathrm{~d}$ at 608 .

90. Id. at 609.

91. Id. at 652 .

92. For a discussion of Camara, 387 U.S. 523 (1967), see infra notes 122-24 and accompanying text. For a more detailed analysis of the $Z$ weibon reasoning, see infra notes $127-40$ and accompanying text. 
ity."93 Although it did not resolve the question of warrantless surveillance of foreign powers or their agents, the plurality's reasoning indicates disagreement with the other circuits and a belief that, absent exigent circumstances, all warrantless electronic surveillance is unreasonable and, therefore, unconstitutional. ${ }^{94}$

In 1978, after six years of preparation and debate, Congress enacted the Foreign Intelligence Surveillance Act (FISA), ${ }^{95}$ which authorizes the executive to conduct electronic surveillance ${ }^{96}$ on foreign powers or their agents. ${ }^{97}$ By requiring a warrant in most situations involving electronic surveillance on United States persons within the territory of the United States, the FISA limits any powers the president may possess to conduct such surveillance. ${ }^{98}$ After an application for an order approving such surveillance is cleared by the Attorney General, it must be submitted to the Foreign Intelligence Surveillance Court.99

93. 516 F.2d at 614 . The eight circuit judges produced five opinions, totalling over 100 pages. Four judges concurred in the plurality opinion, written by Judge Wright. Three judges concurred on statutory grounds. One judge dissented.

94. Id at 613-14.

95. Foreign Intelligence Surveillance Act, Pub. L. No. 95-511, 92 Stat. 1753 (1978) (codified at 50 U.S.C. $\$ 81801-1811$ (1976 \& Supp. IV 1980)).

96. "Electronic surveillance" is defined at 50 U.S.C. \$ 1801(I). If a target is a United States person, citizen or resident alien (defined at 50 U.S.C. § 1801(i) (Supp. IV 1980)) within the United States, and a warrant would be required were the search undertaken for law enforcement purposes, "acquisition" of radio or wire communications intended for that person constitutes electronic surveillance. Id $\S 1801(f)(1)$ (a United States person is not protected by the Act if the person leaves the country). The vast majority of the surveillance activity of the NSA, America's largest spying agency, is not covered by the FISA since section 1801(1)(3) does not include acquisition of international radio communications when a specific individual is not targeted. See $I$. BAMFORD, supra note 44, at 371-72.

The FISA does not define "acquisition." An NSA document states that "acquisition means the interception by the National Security Agency through electronic means of a communication to which it is not an intended party and the processing of the contents of that communication into un intelligible form intended for human inspection." Standard NSA Minimization Procedures, ciled in Schwartz, Oversight of Minimization Compliance Under the Foreign Intelligence Surveillance Act: How the Watchdogs Are Doing Their Jobs, 12 RuTOERs L.J. 405, 410 n.20 (1981). J. BAMFORD, supra note 44, at $372-73$, observes that this language may allow the United States to receive doinestic communications nuonitored by the British Government Communications Headquarters, thus circumventing the Act.

97. "Foreign power" is defined in section 1801(a) as a foreign government or any component thereof, any entity acknowledged by a foreign government to be under its control, a foreign based political organization not substantially composed of United States persons, or a group engaged in international terrorism. An "agent of a foreign power" is defined in section 1801(b). United States persons are not foreign agents unless they "knowingly engage . . . in clandestine intelligence gathering activities for or on behalf of a foreign power, which activities involve or may involve a violation of the criminal statutes of the United States." 50 U.S.C. $\$ 1801(\mathrm{~b})(2)(A)$.

98. See infra notes 142-54 and accompanying text.

99. The Foreign Intelligence Surveillance Court, whose proceedings are shrouded in secrecy, see J. BAMFORD, supra note 44, at 369-70, consists of seven district court judges appointed by the Chief Justice of the United States. The court does not have jurisdiction over electronic surveil- 
The application must state that the target is a foreign power or agent of a foreign power, outline proposed minimization procedures, ${ }^{100}$ describe the nature of the information sought, and certify that the information is foreign intelligence information ${ }^{101}$ that cannot reasonably be obtained by normal imvestigative techniques. ${ }^{102}$ The Foreign Intelligence Surveillance Court must enter an ex parte order approving the surveillance if there is probable cause to believe that the target is a foreign power or agent of a foreign power and the required certifications are not clearly erroneous. ${ }^{103}$ Because the FISA covers only electronic surveillance, and only certam aspects of it, the vitality of a possible constitutional exception to the warrant requirement remains important. ${ }^{104}$

2. Scope of the exception. Because the history of national security surveillance has been largely that of electromic surveillance, the preKatz exemption of electronic surveillance from fourth amendment scrutiny causes much confusion. At least one opinion has reflected the belief that any national security exception to the warrant requirement should therefore be limited to electronic surveillance. Concurring in United States v. Ehrlichman, ${ }^{105}$ Judge Leventhal, who had jomed Judge Wright in $Z$ weibon, argued that even if the national security exception did exist, it should be so limited. Regarding the national security exception as a cancer accompanying electronic surveillance into fourth amendment law after Katz, Judge Leventhal argned first that constitutional protections should not be "whittled away on abstract grounds of

lance directed solely at the acquisition of communications exclusively between foreign powers (e.g., transmissions between the Soviet and North Vietnamese embassies). 50 U.S.C. $\S 1802(a)(1)(A)(i)$.

100. "Minimization procedures," defined at 50 U.S.C. $\$ 1801(\mathrm{~h})$, limit acquisition, retention, and dissemination of information concerning United States persons which is not publicly available.

101. "Foreign intelligence information" is defined at 50 U.S.C. $\$ 1801(\mathrm{e})$ as information relating to, or, if concerning a Umited States person, necessary to, protection from hostile attack, sabotage, international terrorism or clandestine intelligence activities, or the national security or foreign affairs.

102. 50 U.S.C. $\$ 1804(a)(7)(c)$.

103. Id § 1805(a)(3)-(5).

104. In addition, legislation has been introduced that would repeal the Foreign Intelligence Surveillance Act. H.R. 2074, 97th Cong., 1st Sess., 127 CoNG. REC. 652 (Daily Ed.) (Feb. 24, 1981). If the Act is repealed, only the Constitution would protect individual rights from executive discretion in the national security area. Also, both the House and Senate have recently examined proposed legislation that would place further limitations on this type of surveillance. See infra note 165 .

105. 546 F.2d 910 (D.C. Cir. 1976), cert. denied, 429 U.S. 1120 (1977). The case, which involved the legality of the infamous Fielding break-in, was actually decided upon the limited ground that any "natioual security" exception that might exist can only be invoked under specific authorization from the President or Attorney General. 
symmetry."106 However, principled interpretation of the Constitution requires "abstract grounds of symmetry": if the Constitution produces different results in different cases, the need for coherence requires that tenable reasons so dictate. ${ }^{107}$ Second, Judge Leventhal argued that electronic surveillance, differing fundamentally from more traditional searches in terms of intrusiveness, notice, utility, and methodology, should be subject to standards different from non-electronic surveillance standards. ${ }^{108}$ Admittedly, physical entry into the houne was the chief evil appreciated by the framers of the Constitution. ${ }^{109}$ But the Supreme Court in Katz held exphicitly that "[t]he fact that the electronic device employed to aehieve [the desired] . . . end did not happen to penetrate the wall of the [telephone] booth can have no constitutional significance."110 Third, Judge Leventhal suggested that the exception for national security "may be responsive to an assertion that practical realities require a continuous and protracted electronic surveillance . . . that does not lend itself to the warrant procedure."111 This problem is best resolved by applying a flexible probable cause standard, however, rather than by dichotomizing the warrant requirement. ${ }^{112}$

106. Id at 938 .

107. See Wechsler, Toward Neutral Principles of Constitutional Law, 73 HARv. L. Rev. 1595 (1960).

108. Ehrlichman, 546 F.2d at 938 n.9.

109. See Keith, 407 U.S. at 313; Katz, 389 U.S. at 367 (Black; J., dissenting).

110. 389 U.S. at 353 (enphasis added); see Olmstead v. United States, 277 U.S. 438, 478 (Brandeis, J., dissenting) ("To protect that right [to be let alone], every unjustifiable intrusion by the Government upon the privacy of the individual, whatever the means employed, must be deemed a violation of the Fourth Amendment." (einphasis added)). Indeed, many judges and commentators have perceived electronic surveillance to be inherently more imtrusive than more traditional types of surveillance. See, eg., Berger v. New York, 388 U.S. 41, 60 (1967); Olmstead, 277 U.S. at 473 (Brandeis, J., dissenting) (" time works changes, brings iuto existence new conditions and purposes.' . . . Discovery and invention have nade it possible for the government, by ineans far more effective than stretching upon the rack, to obtain disclosure in court of what is whispered in the closet."); Foreign Intelligence Surveillance Act: Hearings Before the Subcomm. on Legislation of the House Permanent Select Comm. on Intelligence, 95th Cong., 2d Sess. 94 (1978) (testimony of John H.F. Shattuck, Executive Director, American Civil Liberties Umion); Foreign Intelligence Surveillance Act: Hearings Before the Subcomm. on Intelligence and the Rights of Americans of the Senate Select Comm. on Intelligence, 95th Cong., 2d Sess. 170 (1976) (exchange between Professors Philip Heyman and Herman Schwartz). Application of the warrant requirement, unlike application of the fourth amendment itself, does not hinge on the intrusiveness of the particular technique employed. Exeeptions are framed with reference to the governmental purpose behind the search, which is independent of the technique einployed to obtain the infornation. See infra text accompanying notes 116-18.

111. Ehrlichman, 546 F.2d at 938 (footnote omitted).

112. As the Keith Court noted, requiring a warrant in cases involving intelligence, as opposed to criminal investigation, does not necessarily mean that the standards for acceptable criminal investigative searches will be imported unchanged into the intelligence context. 407 U.S. at 322 24. 
A final indication that any national security exception might be limited to electronic surveillance, not nentioned by Leventhal, arises from the Supreme Court's treatment of the issue: the Court has never mentioned the national security exception in the context of a physical search. Oddly, the possibility that such an exception might exist was not recognized until 1967, in a footnote to the opmion that brought electronic surveillance within the purview of the fourth amendment, Katz v. United States. ${ }^{113}$ Because Katz had nothing to do with national security, footnote 23 might imply that any national security exception is limited to electronic surveillance. More probably, however, the Court expressly reserved the issue in Katz merely because the national intelligence network has traditionally relied much more heavily on electronic surveillance than on other types of searches. ${ }^{114}$ Overall, no principled distinction can limit the national security exception, if indeed it exists, to electronic surveillance. ${ }^{115}$

\section{Fourth Amendment Analysis of the Supposed "National Security Exception."}

Assuming that the president otherwise has the power to undertake foreign intelligence activities, ${ }^{116}$ he must do so in a manner consonant with the fourth amendment, which contemplates pre-search judicial screening in the form of a warrant application.117 Searches not comporting with that procedure are deeined unreasonable per se, ${ }^{118}$ and thus unconstitutional, unless subject to a recognized exception ${ }^{119}$ to the warrant requirement. Certam searches related to foreign security might well fall into one of the exceptions. 120 The Supreme Court has never ruled, however, on the validity of a blanket exception for all foreign security surveillance. ${ }^{121}$

In Camara v. Municipal Court, ${ }^{122}$ the Court offered the following

113. 389 U.S. 347 (1967).

114. See generally J. BAMFORD, supra note 44.

115. See Zweibon, 516 F.2d at 618-20 n.67; Note, The Fourth Amendment and Executive Authorization of Warrantless Foreign Security Surveillance, 1978 WASH. U.L.Q. 397, 404-06.

116. The limitations inherent in the Constitution's separation of powers, when combined with Congress' intent in passing the FISA, may preciude all such action by the President. See infro notes $155-72$ and accompanying text.

117. See supro note 36 and accompanying text.

118. Katz, 389 U.S. at 357.

119. Id. at 357 \& .19 ; see cases cited supra note 46 .

120. Exceptions particularly relevant to foreign intelligence activities might be those for exigent circumstances, imminent destruction of evidence, or border searches. See supra note 46 and accompanying text; infra text accompanying note 140 .

121. See supra note 74 and accompanying text.

122. 387 U.S. 523 (1967). 
guidelines to determine when an exception to the warrant clause is appropriate:

In assessing whether the public interest deinands creation of a general exception to the Fourth Amendment's warrant requirement, the question is not whether the public interest justifies the type of search in question, but whether the authority to search should be evidenced by a warrant, which in turn depends in part upon whether the burden of obtaining a warrant is likely to frustrate the governmental purpose behind the search. ${ }^{123}$

The reasonableness of the general categories of searches sought to be excepted is irrelevant to this inquiry. The warrant requirement, an enforcement mechanism contained within the substantive body of the fourth amendment, should not be disregarded vis-a-vis a category of cases unless its imposition significantly impedes a substantial, legitimate government purpose.

Thus, in analyzing a possible exception, it is first necessary to identify the government purpose behind the search. Second, the court inust determine the degree to which the burden of obtaining a warrant frustrates that purpose. Finally, the court must weigh the importance of the purpose of the search, discounted by the degree to which it remains unhampered by the warrant requirelnent, against ihe diminution in individual rights imphicit in the loss of effective pre-seizure judicial scrutiny. ${ }^{124}$ Thus, the central inquiry in determining whether a national

123. Id. at 533. The Keith court noted the applicability of Camara to the domestic intelligence context:

If the legitimate need of Government to safeguard domestic security requires the use of electromic surveillance, the question is whether the needs of citizens for privacy and free expression may not be better protected by requiring a warrant before such surveillance is undertaken. We must also ask whether a warrant requirement would unduly frustrate the efforts of Government to protect itself from acts of subversion and overthrow directed against it.

Keith, 407 U.S. at 315.

124. The third requirement is an adaptation of the Learned Hand test, applied to first amendment adjudications im Dennis v. United States, 341 U.S. 494,510 (1951) ("In each case, [courts] must ask whether the gravity of the 'evil,' discounted by its improbability, justifies such invasion of free speech as is necessary to avoid the danger."). Because the Camara Court did not find frustration of the governmental purpose, it did not have to engage in the delicate weighing process required by the third step. If the purpose is frustrated, however, the third step unust follow. See, eg., Keith, 407 U. S. at 299 (Resolution of the problem of warrantless national security surveillance of domestic organizations requires "sensitivity both to the Government's right to protect itself from unlawful subversion and attack and to the citizen's right to be secure in his privacy against unreasonable Government intrusion.") (emphasis added). Sensitivity to competing interests requires a weighing process. Furthermore, the addition of the third step makes seuse of the language of Camara, which states that "whether the authority to search should be evidenced by a warrant . . . depends in part upon whether the burden of obtaining a warrant is likely to frustrate. the governmental purpose behind the search." Camara, 387 U.S. at 533 (emphasis added).

If the balancing process is undertaken, an added factor that may tip the scales is the impact that warrantless searches may have on free expression. This note concentrates on the fourth 
security exception to the fourth amendment warrant requirement is constitutionally justified is whether extenuating circumstances dictate that the executive alone must initially determine the reasonableness of foreign intelligence searches.

1. Purpose. The purpose of foreign intelligence surveillance is clear. In Executive Order 12,333, President Reagan announced that the "United States intelligence effort shall provide . . . the necessary information on which to base decisions concerning the conduct and development of foreign, defense and economic policy, and the protection of United States national interests from foreign security threats." 125 The legitimacy and importance of such a purpose cannot be doubted. ${ }^{126}$ Yet, the gravity of the purpose inust not obscure the true issue: whether imposition of a warrant requirement would impede or frustrate the realization of that purpose.

2. Frustration. As evidence of the warrant requirement's frustration of the purpose of foreign intelligence surveillance, the Justice Department raises several pragmatic justifications for the national security exception, many of which were rejected in Keith in the context of domestic national security.127 First, the Department argues that security matters are too subtle and coinplex for judicial evaluation. The Keith

amendment issues, but in doing so does not imply that the first amendment issues are subordinate or even readily distinguishable.

National security cases . . often reflect a convergence of First and Fourth Amendment values.... The danger to political dissent is acute where the Government atteinpts to act under so vague a concept as the power to protect "domestic security." . . . The price of lawful public dissent must not be a dread of subjection to an unchecked surveillance power. Nor must the fear of unauthorized official eavesdropping deter vigorous citizen dissent and discussion of Government action in private conversation.

Keith, 407 U.S. at 313-14. Certainly the imminent threat of warrantless surveillance might chill otherwise protected expression. For an example, see supra note 9. It might be contended that the first amendment issues are more appropriately addressed in determining the reasonableness of the search rather than whether a warrant should be required before the search. Yet prior review by a magistrate may be the only real hope for protecting the first amendnient rights involved. See supra notes 36-45 and accoinpanying text.

125. Exec. Order No. 12,333, 3 C.F.R. 200, 201, reprinted in 50 U.S.C. $\$ 401$ (Supp. V 1981).

126. See, eg., Korematsu v. United States, 323 U.S. 214, 220 (1944) (sustaining constitutionality of Executive Order No. 9066 and congressional legislation excluding Japanese-Americans from designated "military areas") ("W]hen under conditions of modern warfare our shores are theatened by hostile forces, the power to protect inust be commensurate with the threatened danger.").

127. Although the Keith Court expressly noted that the case required "no judgment on the scope of the President's surveillance power with respect to the activities of foreign powers," 407 U.S. at 308, the Court's reasoning in rejecting a domestic national security exception seems equally applicable to cases of foreign national security. See IOC from Assistant Attomey General Dixon to Attomey General Richardson, reprinted in Joint Hearings on Warrantless Wiretapping and Electronic Surveillance Before the Subcomm, on Administrative Practice and Procedure and the 
Court, noting that "[c]lourts regularly deal with the most difficult issues of our society," 128 found this argument unpersuasive. Judicial incolnpetence will obstruct the purpose of foreign intelligence surveillance only if the judiciary denies warrants that should issue under fourth amendinent standards. In addition to the dearth of evidence revealing any special judicial propensity to err in this field, still less evidence supports the independent conclusion that judicial error will impede foreign intelligence surveillance. ${ }^{129}$ On the whole, the competency argument seeins appropriately subsumed by the pohitical question doctrine: 130 Indeed, if taken to its logical conclusion, the argument would insulate wide categories of conduct froin effective judicial review. ${ }^{131}$

Second, the Justice Department argues that requiring prior judicial approval will threaten the secrecy essential to successful security operations. ${ }^{132}$ The Keith court observed, however, that ex parte warrant applications pose minimal security risks, that judges can be

Subcomm on Constitutional Rights of the Senate Comm on the Judiciary and the Subcomm on Surveillance of the Sert Comm on Foreign Relations, 93d Cong., 2d Sess. 35 (1974):

Although it is true that the Court specifically reserved the foreign intelligence issue, at no point did it volunteer any reasons as to why, as a matter of constitutional law it might be willing to make this distinction when presented with a proper case. To the contrary, the reasoning in Keith seems to anticipate and reject arguments the Department is making at this time in the "foreign intelligence" cases in the lower courts.

128. 407 U.S. at 320.

129. Arguably, if a judge feels incompetent in foreign affairs, he will defer to the government in an ex parte warrant proceeding. This is especially likely if the judge is convinced that national security might be involved. See supra note 44 . If so, frequent judicial errors would result in the government conducting more searches than might reasonably be conducted under the fourth amendment. This result can hardly be said to impede a legitimate governmental purpose.

Many landmark decisions of the Court would never have been decided if the Justice Department's argument was valid. See, e.g., New York Times Co. v. United States, 403 U.S. 713 (1970) (striking down executive attempt to restraim printing of information relating to the Vietnam confict); Youngstown Sheet \& Tube Co. v. Sawyer, 343 U.S. 579 (1952) (invalidating executive seizure of steel mills to facilitate Korean police action).

130. The Court in Baker v. Carr, 369 U.S. 186 (1962), made clear that

it is error to suppose that every case or controversy which touches foreign relations hes beyond judicial cognizance. Our cases in this field seem invariably to show' a discriminating analysis of the particular question posed, in terms of the history of its management by the political branches, of its susceptibility to judicial handling in the light of its nature and posture in the specific case, and of the possible consequences of judicial action.

Id. at 211-12.

The history of the managennent of national security surveillance is inconclusive, see infro notes 173-80 and accounpanying text, and problems involving violation of individuals' civil rights be at the core of the judicial function. The consequences of requiring the executive to obtain a warrant are the focus of the present inquiry.

131. See rupra note 129.

132. 407 U.S. at 319. But see Foreign Intelligence Surveillance Act: Hearings Before the Subcomm on Criminal Laws and Procectures of the Senate Judiciary Comm, 95th Cong., 1st Sess. 27 28 (1977) (testimony of Attorney General Grifin Bell) ("The most leakproof branch in the Gov- 
counted on to be especially conscious of security requirements in such cases, ${ }^{133}$ and that, in any event, special administrative procedures might be employed to minimize leaks. ${ }^{134}$

The Department consistently urges that the warrant requirement was established to regulate investigations preparing for criminal prosecutions, rather than imvestigations designed merely to procure foreign intelligence. ${ }^{135}$ The Department accurately asserts that the warrant requirement relates to the purpose for which information is sought, ${ }^{136}$ but the requirement is not limited to preparation for criminal prosecution. The fourth amendment protects reasonable expectations of privacy, ${ }^{137}$ which may be breached by intrusions not preparatory of criminal prosecution. Indeed, those who have done nothing to arouse suspicion of a criminal violation may have greater expectations of privacy than those who have provoked such suspicion. If the warrant requirement is limited to criminal imvestigatory searches, the second and third prongs of the test inferred from Camara regarding exceptions to the requirement would seem unnecessary. ${ }^{138}$ Once the purpose of the search is ascertained, only those searches intended to gather infornation for criminal proceedings would require warrants. Frustration of the purpose of the search and the relative diminution in imdividual rights would become irrelevant. This result is fundamentally at odds with Camara and other

ernment is the judiciary. . . . The courts have a great record in this area. I'm not worried about them.").

133. The FISA established a special court of seven judges to review presidential requests for warrants to obtain foreign intelligence by electronic surveillance. The Reagan Administration's willingness to conform to this aspect of the FISA, see supra note 5, significantly drains the leak argument of any vitality.

134. 407 U.S. at 320-21. Administrative procedures to prevent leaks of sensitive information have already been successfully established for judicial review of applications to conduct electronic surveillance under the FISA. Under the only published opinion of the FISA court, however, these procedures are not available for applications for warrants to conduct other types of surveillance. See In the Matter of the Application of the United States for an Order Authorizing the Physical Search of Nouresidential Premises and Personal Property, (U.S.F.I.S.C.June 11, 1981), reprinted in H.R. Rep. No. 318, 97th Cong., 1st Sess. 1 app. B (1981). Congress' failure to provide procedures for obtaining other types of warrants for national security searches cannot contract the reach of the fourth amendment. Furthermore, "Congress may not nullify the guarantees of the fourth amendment by the simple expedient of not empowering any judicial officer to act on an application for a warrant." Best v. United States, 184 F.2d 131, 138 (Ist Cir.), cert. denied, 340 U.S. 939 (1950).

135. See, eg., Keith, 407 U.S. at 319; Levi, supra note 56, at 32 ("The Supreme Court has tended to focus not so much on what was physically done, but on why it was done and what the consequence is likely to bo. . . . I stated earlier that a central concern of the Fourth Amendment was with intrusions to obtain evidence to incriminate the victim of the search.").

136. See supra notes 123-24 and accompanying text.

137. Katz, 389 U.S. at 351; see also Griswold v. Connecticut, 381 U.S. 479, 484-85 (1967).

138. See supra notes 123-24 and accoinpanying text. 
case law. ${ }^{139}$ The fourth amendment contemplates pre-seizure warrants regardless of the governmental purpose for the search, unless that purpose is unduly impeded by the warrant requirement.

The Justice Department argues also that foreign affairs often require prompt and decisive action. But the frequent need for swift action im the foreign arena cannot justify a blanket exception to the warrant requirement for all foreign intelligence searches. The exigent circumstances exception to the warrant requirement already embraces those situations in which the necessity of speed renders prior review by a magistrate impractical. ${ }^{140}$ Foreign intelligence surveillances that require prompt action will fall into the exigent circumstances exception; those that do not require such speed should remain subject to the warrant requirement.

3. Balancing. The foregoing discussion demonstrates that the warrant requirement will not significantly impede the purpose behind foreign intelligence surveillance. Thus, as in Camara and Keith, it is unnecessary to pursue the weighing process demanded by the third branch of the proposed test. Because the purpose is not frustrated, no government interest counterbalances the diminution to individual rights flowing from lack of pre-seizure judicial scrutiny. The scales tip decisively in favor of the warrant requirement. Any inconvenience ${ }^{141}$

139. It is surely anomalous to say that the individual and his private property are fully protected by the fourth amenciment only when the indivioual is suspected of crininal behavior. Camara, 387 U.S. at 530. The language of section 2.5 of Executive Order 12,333 (referring to "any technique for which a warrant would be required if undertaken for law enforcement purposes") reflects the Justice Department's view that searches for other purposes, specifically "intelligence purposes," need not conform to the warrant requirement. The confusion probably stems from the use for so many years of the exclusionary rule as the sole mechanism to sanction fourth amendment violations. Almost invariably, illegally seized evidence excluded from criminal prosecutions is the product of investigation preparing for prosecution. Since Bivens, however, monetary damages have been available to compensate vietims. The exclusionary rule, just one remedy inferred from the fourth amendment, does not limit the scope of the rights conferred by the amendment.

140. See supra notes $46 \& 87$.

141. The distinction between frustration and inconverience is primarily one of degree. The weighing process proposed under the third branch is well adapted to account for the sliding scale representing degrees of interference. The mere inconvenience imposed upon the government by requiring it to prepare the necessary papers and other administrative requirements for a warrant application, however, should never, of itself, outweigh the individual rights at stake, regardless of the importance of the purpose of the search. In Steagald v. United States, 451 U.S. 204, 222 (1982), the Court noted:

Any warrant requirement impedes to some extent the vigor with which the Government can seek to enforce its laws, yet the Fourth Amendment recognizes that this restraint is necessary in sone cases to protect against unreasonable searches and seizures. . . . The burden imposed on the potice by a warrant requirement is minimal. In contrast, the right protected-that of presumptively innocent people to be secure in their homes from unjustified, forcible intrusions by the Government - is weighty. 
imposed on the executive by the warrant requirement is substantially outweighed by the protection of privacy expectations.

It follows, therefore, that a general national security exception to the fourth amendment warrant requirement does not satisfy the guidelines articulated by the Supreme Court in Camara. To the extent Executive Order 12,333, section 2.5 , relies on such an exception to avoid securing pre-search warrants for foreign intelligence surveillance searches, the Order is unconstitutional.

\section{Congressional Restrictions on Executive Power to Conduct National Security Searches}

The above analysis concludes that the fourth amendment does not permit a general national security exception to the warrant requirement. An additional constitutional constramt on any executive authority to collect foreign intelligence infornation may be found in Congress' power under article I to shape executive prerogative by making "all laws . . . necessary and proper for carrying into execution . . . all . . . Powers vested by . . . [the] Constitution in . . . any . . . officer of the United States."142 Either of these constitutional constraints the fourth amendment or congressional restriction pursuant to the necessary and proper clause - is sufficient, standing alone, to limit the President's purported power under Executive Order 12,333.

The classic exposition of the interaction of congressional attitudes and executive power was provided by Justice Jackson in his concurring opimion in Youngstown Sheet \& Tube Co. v. Sawyer . ${ }^{143}$ Justice Jackson recognized three paradigms:

1. When the President acts pursuant to an express or implied authorization of Congress, his authority is at its maximum . . . . 144

2. [When he] acts in absence of either a congressional grant or demal of authority, he can rely only upon his own imdependent powers . . . . 145

142. U.S. Const. art. $1, \S 8$, cl. 18.

143. 343 U.S. 579 (1951).

144. Id. at 635. "If his act is held unconstitutional under these circumstances, it usually means that the Federal Government as an undivided whole lacks power." Id. at 636-37. Although this note concludes that Congress has not authorized the President to engage in warrantless national security searches, see supra notes $155-80$ and accompanying text, the constitutional arguments addressed infra at note 164 and accompanying text indicate that such searches, even if Congressionally authorized, would still be unconstitutional.

145. 343 U.S. at 637. "[B]ut there is a zone of twilight in which he and Congress may have concurrent authority, or in which its distribution is uncertain. Therefore, congressional inertia, indifference, or quiescence may sometimes, at least as a practical matter, enable, if not invite, measures on imdependent presidential responsibility. . . " Id. 
3. [When he] takes measures incompatible with the expressed or implied will of Congress, his power is at its lowest ebb . . . . ${ }^{146}$

More recently, the Supreme Court has noted that "executive action in any particular instance falls, not neatly in one of three pigeonholes, but rather at some point along a spectrum running from explicit congressional authorization to explicit congressional prohibition." 147 Thus, it is first necessary to determine the power of Congress to restrict or expand the legitimate scope of executive discretion. Then the actual exercise by Congress of its power must be gauged along this spectrum.

Congress has broad power to regulate the exercise of any presidential power to conduct foreign intelligence surveillance. ${ }^{148}$ No exphcit constitutional grant unambiguously gives the President such power. ${ }^{149}$ Youngstown seeins decisive: if the President cannot, in the face of congressional hostility, seize steel mills when he considers the nation's security imperiled, he cannot conduct searches and seizures under similar conditions. ${ }^{150}$ It would be anomalous to hold that Congress has greater capacity to protect individual property rights than those personal rights

146. Id In this situation the president "can rely only upon his own constitutional powers minus any constitutional powers of Congress over the matter. Courts can sustain exclusive presidential control in such a case only by disabling the Congress from acting on the subject." Id.

147. Dames \& Moore v. Regan, 453 U.S. 654, 669 (1981).

148. See Levi, supra note 56, at 18 (future Presidents will be required to adhere to the standards established by Congress in enacting the FISA). H. R. REP. No. 1283, pt. 1, 95th Cong., 2d Sess. 24, 101 (1978). But see Hearings Before the Subcomm on Criminal Laws and Procedures of the Senate Judiciary Comm, 94th Cong., 2d Sess. 69 (1976) (testimony of Dean Louis Pollack) ("As a technical matter, it is not necessary for legislation by Congress to include a disclaimer of purpose to limit the inherent presidential power in whatever area, because whether Congress intends to limit or does not intend to limit such power, it has no authority so to do."); supra note 84.

Perhaps Dean Pollock's assertion is explained by its reference to "inherent powers," presumably derived from an extra-constitutional source. See supra note 15 . The necessary and proper clause establishes congressional primacy only with respect to powers based upon those granted in the Constitution. Although this argument has some force, it seems that (1) the existence of any "inherent powers" is a matter of grave uncertainty, see supra notes 21-22 and accompanying text, and (2) even if "inherent powers do exist, the scheme of the constitution, establishing congressional primacy, should be read to enable Congress to define and place reasonable restrictions on such powers.

With all its defects, delays and inconveriences, men have discovered no technique for long preserving free government except that the Executive be under law, and that the law be made by parliamentary deliberations.

Such institutions may be bound to pass away. But it is the duty of the Court to be last, not first, to give them up.

Youngstown, 343 U.S. at 655 (Jackson, J., concurring).

149. See infra note 127 and accoinpanying text.

150. The Court in Youngstown declared executive seizure of steel mills in the face of an imminent strike to be unlawful, even though President Truman contended that the seizure was necessary for the national security in light of the "potice action" then underway in Korea. Congress had adopted a legislative schene for regulating labor conflicts that intentionally excluded the pussiviuny un unilateral executive seizure. 
Justice Brandeis aptly described as most valued by civilized men. ${ }^{151}$ The president is not a "Lone Ranger" 152 in the field of foreign affairs or in the more specialized area of national security. Indeed, if the President were free to invoke national security to ignore the will of Congress, wide categories of legislation might be rendered nugatory. ${ }^{153}$ Powers explicitly granted to the legislative branch by the Constitution would be eroded. ${ }^{154}$ Thus, Congress possesses substantial power to regulate executive activity relating to foreign intelligence surveillance; it now becomes necessary to determine the extent to which Congress lias exercised this power.

Although determining congressional intent is difficult, the available evidence indicates congressional hostility toward warrantless searclies. Certainly, the FISA displays congressional intent that the executive submit to pre-seizure judicial scrutiny when it wishes to conduct electronic surveillance within the United States. ${ }^{155}$ With regard to Congress' intent to restrict executive prerogative to conduct non-electronic surveillance, three mutually exclusive inferences, corresponding to Justice Jackson's three paradigms, may be drawn from passage of the FISA. First, im enacting the FISA and requiring the executive to submit to pre-seizure judicial scrutiny in the area of electronic surveillance, Congress impliedly approved warrantless national security sur: veillance that employed other methods. Failure to prohibit other types of surveillance arguably implies consent. ${ }^{156}$ Second, limiting the

151. See supra note 52 .

152. Butenko, 494 F.2d at 611 (Seit, C. J., concurring and dissenting).

153. If the President disagreed with legislation regulating, for example, school lunch subsidies or importation of automobiles, few would coutend that he could simply ignore Congress. Yet that result would seem to follow if the "national security" could mysteriously be invoked to ignore congressional power. The federally subsidized school lunch program was initiated after the government discovered during World War II that many underprivileged, malnourished youths were physically incapable of serving in the armed forces. See Pear, "New Federalism" Threatens Nutrition Program, Tampa Tribune, January 3, 1983, \& A, at 13. Similarly, the continued capacity of U.S. industry to produce automotive vehicles is arguably essential for national security.

154. Examples include the power to ratify treaties, U.S. CoNST. art. II, \& 2, cl. 2, the power to raise and support armies, U.S. CoNST. art. I, \& 8, cl. 12, and the power to provide for and maintain a navy, U.S. ConsT. art. I, \& 8, cl. 13.

155. The permissibility of warrantless electronic surveillance, at least within Umited States borders, is not in dispute because Executive Order 12,333 submits to the FISA in the area of electromic surveillance. See supra note 5 and accompanying text.

156. This accords with the traditional but inuch inaligned rule of construction, expressio unius est exclusio alterius - expression of one is the exclusion of all others. On the other hand, it might be argued that this maxim supports the notion that Congress impliedly banned all other forms of surveillance by explicitly allowing only one type of surveillance. Thus, the result of the application of expresio unius est exclusio alierius would hinge on whether Congress was expressing a limitation of certain types of surveillance previously practiced by the executive, or approval of certain practices not previously authorized. See Electronic Surveillance within the United States for Forelgn Intelligence Purposes: Hearings on Intelligence and the Rights of Americans of the Senate 
FISA's coverage to electronic surveillance implies nothing about other types of surveillance, nerely leaving presidential powers untouched in other areas. Third, restricting executive power to conduct warrantless foreign security electronic surveillance indicates general disapproval of warrantless foreign security searcles. ${ }^{157}$ The third alternative is the most logical and inost coinpatible with the legislative history.

Congress passed the FISA in the aftermath of the Keith case and the abuses that occurred during the Watergate years. It is reasonable to assume that Congress believed the courts would require the president and the investigative agencies to obtain warrants before conducting searches, as defined in Katz. Therefore, Congress presumably passed the FISA to ensure that agencies could conduct electronic surveillance within the country in a clandestine inanner: the Act creates a secret court to review all applications for warrants for such surveillance. The Act does not create a similar procedure either for non-electronic surveillance within this country or for surveillance outside the country; lowever, Congress probably intended that electronic surveillance within the country receive special protections. Foreign intelligence surveillance by the United States rarely takes the form of non-electronic searches, and surveillance outside the United States, if it falls within the warrant requirement at all, ${ }^{158}$ poses problems distinct froin domestic surveillance. ${ }^{159}$ Surely Congress did not intend to require warrants for electronic surveillance but exenipt entirely from the warrant requirenient other types of intrusive surveillance. This view is reinforced by 18 U.S.C. $\$ 2236,160$ which imposes criminal penalties on federal employees engaged in law enforcement who search private dwellings without authorizing warrants. Warrantless searches of private dwell-

Select Comm on Intelligence, 94th Cong., 2d Sess. 56 (1976) (testimony of Senator Mondale) ("this bill establishes directly the authority that has been missing until now to conduct so-called domestic intelligence against Americans"); gf. Marbury v. Madison, 5 U.S. (1 Cranch) 137 (1803) (holding that Congress imphiedly withdrew all judicial jurisdiction that it did not grant under the Judiciary Act of 1789).

157. This inference is consistent with the concept that electronic surveillance poses no grcater threat to individual freedoms than other types of searches. See supra notes 105-15 and accompanying text.

158. See infra note 165.

159. See Foreign Intelligence Surveillance Act of 1978: Hearings Before the Subcomm. on Intelligence and the Rights of Americans of the Senate Select Comm on Intelligence, 95th Cong., 2d Sess. 16 (1978) (prepared statement of Attorney General Bell) ("[T] Je Justice Department, in coordination with members of the various affected intelligence agencies, is actively at work on developing a proposed bill to extend statutory safeguards to Americans abroad . . . . There are . . . special problems involved in overseas surveillances.) See also id. at 63 (prepared statement of Deanne Siemer, General Counsel, Department of Defense).

160. 18 U.S.C. \& 2236 (1976). The section does not apply to consensual searches or searches incident to arrest. 
ings thus fly in the face of clearly expressed congressional intent. Other warrantless searches should be subjected to close scrutiny.

The reports of the Church ${ }^{161}$ and Pike Committees ${ }^{162}$ support this analysis. As the Church Committee noted, "we have seen segments of our Government adopt tactics unworthy of a dennocracy and occasionally reminiscent of the tactics of totalitarian regimes. . . . Clear legal standards and effective [congressional] oversight and controls are necessary."163 Examination of the legislative history of the FISA also sup-

161. Senate Select Comm. to Study Governmental Operations with Respect to INtelligence Activities, Intellioence Activities aNd the Rights of Americans, S. Rep. No. 755, 94th Cong., 2d Sess., bk II (1976) [hereinafter cited as ChURCH CoMm.].

162. The recommendations of the final report of the Pike Committee are contained in H. REP. No. 833, 94th Cong., 2d Sess. (1976). The actual 238 page final report was suppressed by the House over the urging of the Committee by a 246 to 124 vote on January 29, 1976. The report had been leaked to Daniel Schorr of CBS and published, in part, by the New York Times. House Comm. Firds Intelligence Agencies Generally Go Unchecked, N.Y. Times, Jan. 26, 1976, § 1, at 4, col. 6. On February 11, a New York weekly newspaper, The Village Voice, published substantial parts of the report. The Report on the CIA that President Ford Doesn't Want You to Read, Village Voice, Feb. 16, 1976, at 69-92. See generally, 32 Cong. Almanac 330-38 (1976). Schorr eventually resigned froin his position with CBS.

163. ChURCh CoMm., supra note 161, at 3-4; see also Foreign INTELLIGENCE SURVEILLANCE ACT OF 1976, S. REP. No. 1035, 94th Cong., 2d Sess. 9-10 (1976) [hereinafter cited as 1976 SENATE REPORT].

The bill can provide effective, reasonable safeguards to ensure accountability and prevent improper surveillance. . . . The need for such statutory safeguards has become all too apparent in recent years. This legislation is in large measure a response to the revelations that warrantless electronic surveillance in the name of national security has been seriously abused. These abuses were first illuminated in 1973 during the investigation of the Watergate break-in and have since been chronicled in more detail by the Church Committee.

Id

In the early part of this decade it became apparent that the constitutional rights of Americans were imperiled by activities being carried out under the guise of national security. . . . In order, as they thought, to protect America our intelligence agencies were transgressing the rights of Americans.

To rectify this, the Committees on Intelligence were created.

National Intelligence Act of 1980: Hearings on S. 2284 Before the Senate Select Comm. on Intelligence, 96th Cong., 2d Sess. 110 (1980) (testimony of Senator Sehweicker).

We do not have to remind the chairman and most inembers of this committee of the principal reason charter legislation is before the Congress today. It was the revelation of violations of citizens' rights which led Congress to investigate the intelligence agencies. It was congressional documentation of even more widespread violations of civil hiberties than originally imagined which led to the call for charters, the creation of this committee with a inandate to develop charters, and the introduction of legislation in 1978, S. 2525. However, for those who are new in the Congress, and to underscore the significance of those sections authorizing and purportedly restricting inteliigence activities directed at Americans, we believe the summary of the Senate Select Committee worth quoting in brief. We quote from page 5 of the final report:

Too many people have been spied on by too many government agencies.. - even when their beliefs posed no threat of violence or illegal acts on behalf of a hostile foreign power. The Government, operating primarily through secret inforunants, but also using other intrusive techniques such as . . . mail opening, and break-ins, has swept in vast amounts of infornation . . . . Unsavory and vicious tactics have been employed.

Id at 146 (testimony of Jerry J. Bcrman, Legislative Counsel, ACLU). 
ports the inference drawn from its passage: Congress disapproved generally of warrantless searches that merely invoke "national security" for justification. The Church Committee Report, relied on heavily by the framers of the FISA, ${ }^{164}$ suggested that both electronic surveillance and physical searches "be conducted only upon judicial warrants." 165 The Senate Judiciary Committee, in its report on the FISA,

164. See 1976 SENATE REPORT, supra note 163 , at 79-80.

165. Church Comm., supra note 161, at 328 (Recommendation 54). Originally, Congress intended to legislate on the entire field of surveillance. The following excerpts are instructive:

Senator Hathaway: The other area is that although this bill limits itself to wiretapping, it does not apply to hidden cameras or break-ins or anything like that.

Att'y Gen. Bell: Right.

Senator Hathaway: Why shouldn't we cover every kind of mechanism that's going to invade the privacy of individuals?

Att'y Gen. Bell: We are preparing legislation on those other areas.

Foreign Intelligence Surveillance Act: Hearings Before the Subcomm. on Intelligence and the Rights of Americans of the Senate Select Comm on Intelligence, 95th Cong., 2d Sess. 38-39 (1978) (testimony of Attorney General Griftin Bell).

It [the FISA] is an extremely important piece of legislation for two reasons. First, it will set the ground rules for the use of electronic surveillance in intelligence cases, a technique which has been widely used in the past. Second, in setting such rules for electronic surveillance, it will establish a precedent and undoubtedly have an impact on congressional treatment of other intrusive investigative techniques such as mail covers and surreptitious entries.

Foreign Inteiligence Surveillance Act: Hearings Before the Subcomm on Intelligence and the Rights of Americans of the Senate Select Comm on Intelligence, 94th Cong., 2d Sess. 2 (1976) (remarks of Senator Birch Bayh); see also Foreign Intelligence Surveillance Act of 1978: Hearings Before the Subcomm on Intelligence and the Rights of Americans of the Senate Select Comm. on Intelligence, 95th Cong., 2d. Sess. 50-51 (1978) (testimony of Admiral Stansfield Turner, Director of the Central Intelligence Agency).

Indeed, sipilar legislation was introduced by Senator Matthias in 1975. The Bill of Rights Procedure Act would have required any federal agent to obtain a court order before conducting any form of surveillance on a private citizen. In 1980, committees in both the Senate and House considered legislation that proposed to establish detailed guidelines for the conduct of United States intelligence activities. National Intelligence Act of 1980, S. 2284, 95th Cong., 2d Sess. (1980), H.R. 6588, 96th Cong., 2d Sess. (1980). In unany respects, the proposed legislation was designed to supersede the Executive Order. Title VI of the bill would have established a legislative mandate for the NSA, the largest branch of the intelligence network. The NSA, which, unlike the CLA, is not subject to the provisions of the National Security Act of 1947, currently has no statutory basis for its existence; its theoretical base evidently rests on the "inherent powers" of the President. Title VIII of the proposal would have amended the FISA to encoinpass physical searches. The amendment would also have expanded the FISA to imclude search of property or opening of mail under circumstances in which a person would have a reasonable expectation of privacy and a warrant would be required for law enforcement purposes.

Title II of the proposed legislation would also have extended limited protection to United States persons overseas, though considerably less than that afforded to United States persons within this country. Although judicial approval of overseas surveillance would be required, such approval would be automatic if the executive determined that the information sought was "essential" to the national security - whether or not the target could be labeled as an agent of a foreign power. National Intelligence Act of 1980, Hearings Before the Sentate Select Comm on Intelligence, 96th Cong., 2d Sess. 159, 161 (1980). For a prior atteinpt at similar legislation, see S. 525, 95th Cong., 2d Sess. (1978), H.R. 11,245, 95th Cong., 2d Sess. (1978). 
expressed its belief that the president had no power to conduct warrantless surveillance. ${ }^{166}$

Moreover, Senate Bill 3617, which ultimately became the FISA, originally included a provision intended to limit the scope of the national security proviso of the 1968 Omnibus Crime Control and Safe Streets Act:167 "Nothing contained in this chapter shall be deemed to affect any constitutional power the president may have to acquire foreign intelligence information if (a) such acquisition does not coine within the definition of electronic surveillance. ..."168 In comment-

Attorney General Levi has argued that the fourth amendment protects only United States citizens and thus has no application to foreign powers or their agents. See Levi, supra note 56, at 30. This argument is flawed in two zespects. First, many of those that may be labelled agents of foreign powers by the Attorney General may also be United States citizens. Section 2.5 of Executive Order 12,333 recognizes as mucl when it authorizes use of intelligence techniques against United States persons (citizens, corporations, or permanent resident aliens) abroad. Second, the language of the fourth amendment gives no hint that it protects only citizens. The amendment protects the "right of the people," without specifying which people are protected. Indced, by implying that it protects a preexistent right rather than creating a new right, the language favors a broad interpretation. On the other hand, it is possible to argue that "the people" of the fourth amendment corresponds to the "we the people" of the preamble to the Constitution, thus narrowing the ambit of its coverage. Although the scope of the amendment remains unclear, it is now establislred that it does protect non-citizen resident aliens, see Au Yi Lau v. United States, 445 F.2d 217, cert. denied, 404 U.S. 864 (1971), as well as United States citizens living abroad. See Berlin Democratic Club v. Rumsfeld, 410 F. Supp. 144 (D.D.C. 1976); cf. Reid v. Covert, 354 U.S. 1 (1957); Saltzburg. The Reach of the Bill of Rights Beyond the Terra Firma of the United States, 20 VA.J. INT'L L. 741 (1980). One federal appellate court has extended the amendment's protections to non-United States citizens living abroad. See United States v. Toscanino, 500 F.2d 267 (2d Cir. 1974). The Toscanino court stated:

It is beyond dispute that an alien may invoke the Fourth Amendment's protection against an unreasonable search conducted in the United States. . . . No sound basis is offered in support of a different rule with respect to aliens who are the victims of unconstitutional action abroad, at least where the government seeks to exploit the fruits of its unlawful conduct in a criminal proceeding against the alien in the United States.

Id. at 280; see also National Intelligence Act of 1980: Hearings Before the Subcomm on Legislation of the Senate Select Comm. on Intelligence, 96th Cong., 2d Sess. 332-33 (1980) (testimony of Griffin Bell).

Further provisions of the proposed 1980 act on counterintelligence seemed to einasculate some of the protections of the FISA. One group complained that the bill read "the way we might imagine the Fourth Amendment to read if drafted by a committee of police chiefs." Id. at 154 (testimony of Jerry J. Berman, Legislative Counsel, ACLU). Nevertheless, Attorney General William French Smith argued that the bill did not go far enough in facilitating foreign intelligence collection. He proposed amendments to the FISA, apparently favoring the weaker "essential to the national security" formulation in domestic as well as overseas searclies. Id. at 213-14. Indeed, the Attorney General suggested that the FISA had contributed to the "Imperial Judiciary." Id. at 213.

166. 1976 SENATE REPORT, supra note 163 , at $79-80$.

167. Section 2511 (3), the national security proviso of the 1968 Act, is described supro note 67 and accompanying text. The proviso lad been inconspicuously slipped into the 1968 Act at the beliest of Roy Banner, the chief counsel for the National Security Agency. See J. BAMFORD, supra note 44 , at 256 . The proviso was utimately repealed by the FISA.

168. I976 SENATE REPORT, supra note 163 , at 49 (\$2528). The proviso "would assure that every situation important to the national interest would be covered - either by the warrant procedure of the Bill or by the President's inherent constitutional power . . . to conduct electronic 
ing on the provision, Professor Schwartz testified before the Senate Judiciary Committee:

I think what is terribly important . . . is that this bill may be a precedent, not only for intelligence obtained for national security purposes in the domestic area but it may also be a precedent for cutting into fourth and first amendment limitations by other means, namely by burglary and the like. ${ }^{169}$

Significantly, the final version of the bill dropped the disclaimer language. ${ }^{170}$ This seems to indicate an intent to restrict any inherent power that might exist outside the electronic surveillance field. ${ }^{171}$ Furthermore, in its final report on the legislation, the House Committee stated that the FISA would "inoot the debate over the existence or nonexistence of . . power to authorize warrantless searches in the United States in the absence of legislation." 172

It might be argued that, in the light of a history of warrantless foreign security surveillanee, congressional failure to exphcitly proscribe warrantless foreign security surveillance constitutes acquiescence. In Youngstown, Justice Frankfurter, concurring, noted that "a systematic, unbroken, executive practice, long pursued to the knowledge of Congress and never before questioned . . . may be treated as a

surveillance with respect to foreign powers." Senate Bill 3197: Hearing Before the Subcomm. on Criminal Laws and Procedures of the Senate Judiciary Comm, 94th Cong., 2d Sess. 12-13 (1976) (testimony of Attorney General Levi).

169. Foreign Intelligence Surveillance Act: Hearings Before the Subcomm on Criminal Laws and Procedure of the Senate Judiciary Comm, 94th Cong., 2d Sess. 51 (1976) (testimony of Professor Herman Schwartz).

170. The elimination of the disclaimer language might be linked to a wemorandum submitted by the ACLU, noting the recent Ehrlichman decision, see supra notes 105-15 and accompanying text, and warning that the disclaimer left "intact Presidential assertions of power to collect foreigu intelligence information by all and any means not covered by the statute." Foreign Intclligence Surveillance Act: Hearings Before the Subcomm on Intelligence and the Rights of Americans of the Senate Select Comm. on Intelligence, 94th Cong., 2d Sess. 211 -12 (1976) (memorandum froin Hope Eastman, Associate Director, Washington office, American Civil Liberties Umion). Interestingly, Senator Tunney, dissenting from the 1976 Senate Report, urged that section 2528 be removed:

I agree with the Church Committee which said that "while the constitutional issue has not been resolved, the committee does not betieve that the President has inherent power to authorize the targeting of an American for electronic surveillance without a warrant. I believe that this bill should close the loophole of presidential prerogative.

1976 SENATE REPORT, supra note 163, at 142; see also Electronic Survcillance Within the United States for Foreign Intelligence Purposes: Hearings Before the Subcomm on Intelligence and the Rights of Americans of the Senate Select Comm on Intelligence, 94th Cong., 2d Sess. 56 (1976) (testimony of Senator Mondale).

171. See Youngstown, 343 U.S. at 586 (rejection of an amendment implies rejection of the substance thereof).

172. Foreign Intelligence Survemlance ACt, H. R. Rep. No. 1283, pt. 1, 95th Cong., 2d j̄os. 24 (1978). 
gloss on 'executive power." "173 Warrantless non-electronic surveillance does not pose such a case. First, any pre-1967 "congressional acquiescence" is of dubious significance ${ }^{174}$ in light of the pre-Katz exemption of electromic surveillance froin the fourth amendment. Virtually all visible national security surveillance prior to $K a t z$ was electronic in nature. Any passive congressional acquiescence in its use might be applicable to the construction of section 605 of the Federal Communications Act, ${ }^{175}$ but is irrelevant to acquiescence in a general exception to the fourth amendment warrant requirement. ${ }^{176}$

Although the executive also engaged in physical trespasses when installing microplones, ${ }^{177}$ not until the Silverman ${ }^{178}$ decision in 1961 was such activity held subject to the fourth amendment. As late as 1965 , President Johnson recognized that "[u]tilization of nechanical or electronic devices to overhear nontelephone conversations is ... . [a] difficult problem which raises substantial and unresolved problems of constitutional adjudication."179 Since that time, the turmoil surrounding the claimed national security exception, coupled with its timid and infrequent exercise by the President, as well as the enactment of the FISA, negates any inference of acquiescence. Furthermore, even if, as Frankfurter suggested, the executive niay augnent his power by resort to a species of "adverse possession," longstanding practices must have

173. Youngstown, 343 U.S. at $610-11$. It is important to note that this silence operates only as a species of implied consent. Thus, this "gloss" on executive power is of statutory - not constitutional - origin and may be removed by Congress at its discretion. Congress does not, by its inaction, lose its power to regulate executive activity.

174. Such acquiescence followed ineluctably from the Court's decision in Olmstead v. United States, 277 U.S. 438 (1928), overruled, Katz v. United States, 389 U.S. 347 (1967). See supra notes $50-64$ and accompanying text.

175. See supra notes 53-57 and accompanying text.

176. Cf. Zweibon, 516 F.2d at $617-18$ (refuting suggestion that presidents had, in construing Nardone, asserted freedom froin fourth ameudment warrant procedures).

177. See supra notes $59-61$ and accompanying text.

178. Silverman v. United States, 365 U.S. 505 (1961).

179. Memorandum from President Johnson, supra note 60 and accompanying text. Wiretapping, of course, did not present such problems to the president, because it did not involve an initial trespass in order to install the mechanical device. See Zweibon, 516 F.2d at 616-19. Cf. Youngstown, 343 U.S. at 612 n.20 (Frankfurter, J., concurring) (if the executive conceives himself as operating within a certain law, snbsequent invalidation of that law does not support the proposition that he would have felt the power to act had no such law existed). In 1969, the Huston Plan, prepared under the direction of White House Legal Counsel Tom Charles Huston and for a brief period approved by the President, dealt separateIy with electronic surveillance and surreptitious entry. With regard to the latter, Huston noted that "[u]se of this technique is clearly illegal: it amounts to burglary. It is also highly risky, and could result in great embarassment if exposed. However, it is also the most fruitful tool and can produce the type of intelligence which cannot be obtained in any other fashion." Domestic Intelligence Gathering Plan: Analysis and StrategyOperational Restraints on Intelligence Collection, July, 1970, reprinted in J. BAMFORD, supra note 44, at 273 (emphasis added). 
been pursued with the full knowledge of Congress to support such augmentation. ${ }^{180}$ The essence of foreign security surveillance is secrecy; many of the executive's longstanding practices have been uncovered only im recent years. Congress cannot be deemed to have acquiesced im conduct of which it was, for the most part, ignorant.

\section{CONCLUSION}

The fourth amendment generally requires that, prior to instituting a search, the government submit the proposed search to judicial scrutiny. Executive Order 12,333 recognizes no such constitutional obligation in cases in which the Attorney General directs that surveillance be directed against "an agent of a foreign power," a term which remaims undefined. However, any power that the executive branch possesses to conduct foreign intelligence surveillance must be exercised subject to the restrictions of the Constitution. This note has examined two independent restrictions on that power. Either restriction is sufficient alone to restrain the prerogative the President claims under the Order.

First, the fourth ainendment precludes the possibility of a general national security exception. The warrant requirement does not unduly frustrate the legitimate purpose underlying the collection of foreign intelligence information. The requirement does not prevent the executive from collecting sensitive data essential to the nation's security; it merely demands that, prior to the implementation of intrusive techniques, he secure a judicial warrant. ${ }^{181}$ This prerequisite strikes a reasonable balance between the legitimate goals of intelligence collection and the rights of freedom and privacy which lie at the core of our constitutional scheme. Alternatively, congressional hostility to a national security exception limits its scope. In either case, Executive Order 12,333, section 2.5 , fails to coinply with the applicable constitutional constraints. The Order is therefore invalid.

David S. Eggert

180. See, eg., Dames \& Moore v. Regan, 453 U.S. 654,686 (1981); Haig v. Agee, 453 U.S. 280, 300 (1981).

181. In Zweibon v. Mitchell, 516 F.2d 594 (D.C. Cir. 1975) (en banc), cert. denjed, 425 U.S. 944 (1976), Judge Wright pointed out in the plurality opinion that:

In referring to the warrant requirement as "procedural," we do not mean to imply that it does not have important substantive aspects and purposes. Rather, we employ the term to contrast the existence and scope of any executive power to gather information with the safeguards pursuant to which such power is to be exercised. Id. at 616 n. 52 . 